\title{
دور الإرشاد الزراعي في تنمية المرأة الريفية في بعض قرى \\ محافظة إب - الجمهورية اليمنية
}

\section{درية محمد خيري و أحمد الهنيدي رضوان و عصام سبا أحمد شاهين و إيمان أحمد عبده سيف قسم الإرشاد الزراعي والمجتمع الريفي - كلية الزراعة جامعة المنوفية- شبين الكوم- مصر}

Received: Apr. 30,2017

Accepted: May 5, 2017

الملخص

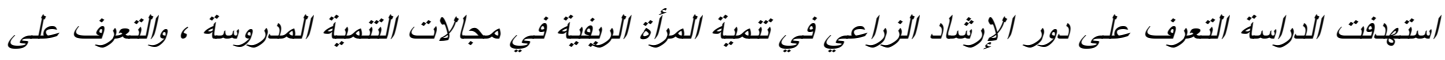

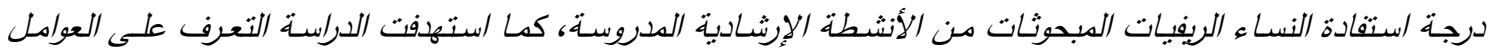

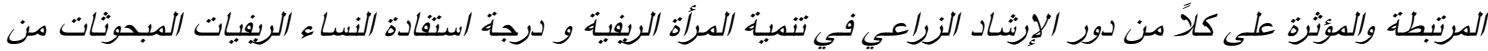
الأنشطة الإشادية، والتعرف على الدعوقات التي تدـ من استفادة المجوثات من الأنشطة والبرامج الإشادية. وقد أجريت

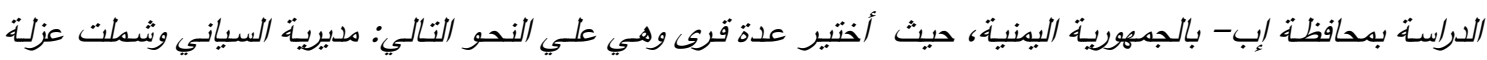
النقبلين واختبر منها قري (الجزنم و رقاد و ني الدحم)، ومديرية بعدان وشملت عزلة الدعبس و واختبر هنها قرى ( جحاره

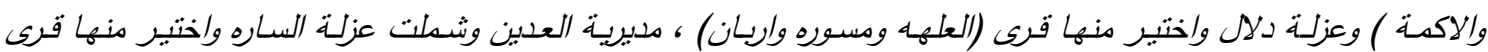

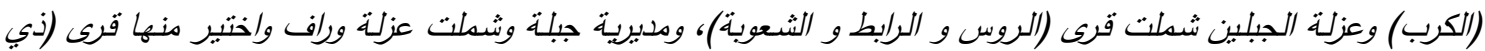

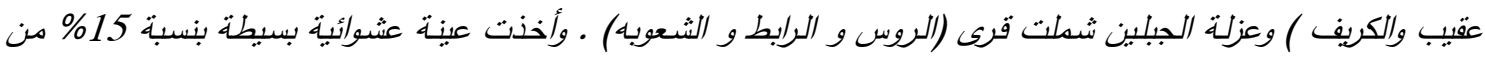

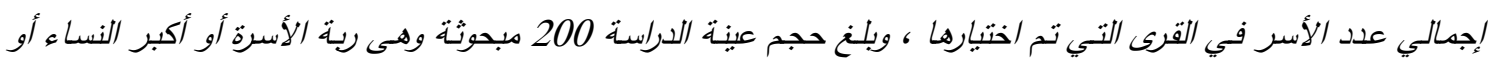

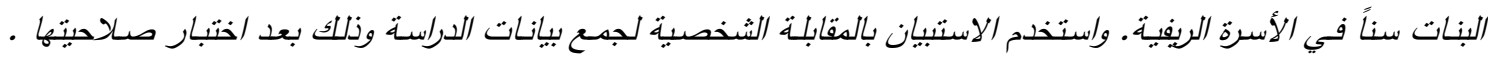
واشتملت الدراسـة علي عدة متغيرات بحثية بعضها بغـرض وصف العينـة والأخرى بغـرض التحليل ـ واستخلم البرنـامج الاحصائي SPSS في تحليل بيانات الدراسة ، وتم الاستعانة بعدة اساليب إحصائية كالتكرارات والنسب المئوية والتنوزيع

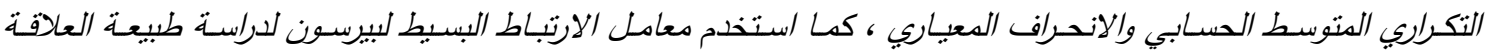

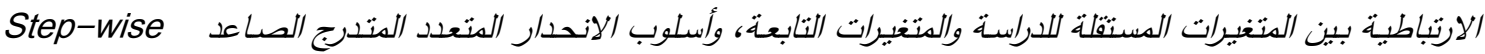
Multiple correlation and Regression Analysis وذلك لتحديد الإسهام النسبي لكل من المتغيرات المستقلة مجتدعة التي ثبت معنوية علاقتها في الكتغبر التابع. وأسفرت الدراسة عن عدة نتائج تمثلت /هدها في الاتي : 1- هناك علاقة ارتباطية طردية عند دستوى دعنوية 0,01 بين الدرجات الدعبرة عن قيام الإثاد الزراعي في تتفيذ الانثطة في مجالات التنمبة الددروسة وبين كل من الدتغيرات الدستقلة

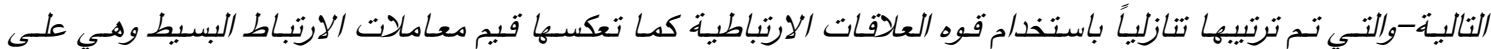
الترتيب-: التـريب و المشـاركة غير الرسمية والإنفتاح الثقافي و والمشـاركة الدنظمية (0,434)، (0,363)، (0,249)، (0,248)، كذلك توجد علاقة ارتباطية موجبة عند مستوى معنوية (0,05) بين درجة قيام الإشاد الزراعي في تتفيذ الانشطة

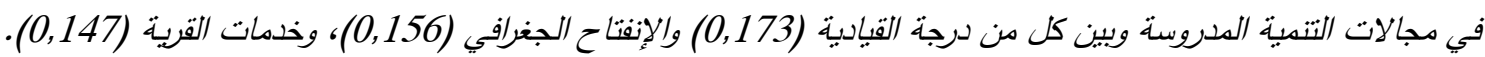
وهناك علاقة إرتباطية عكسية عند مستوى معنوية 0,01 ببين درجة قيام الإشاد الزراعي في تتفيذ الانشطة في مجالات التتمية الددروسة والسن(0,282)، وكنلك وجود علاقة أرتباطية عكسبة عند مستوى معنوية 0,05 بين درجة قيام الإشاد

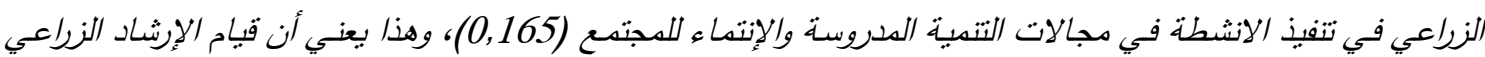




\section{Doria M. Khairy, et al.,}

في تتفيذ الانشطة في مجالات التندية الددروسة بئأثر سلبياً بسن المبحوثة والانتماء للمجتدع. 2- هناك أربعة متغيرات

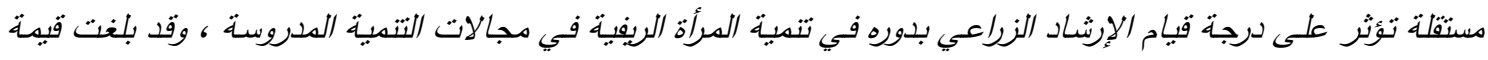

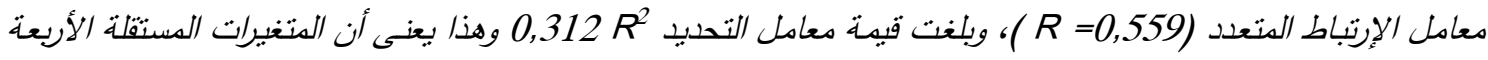

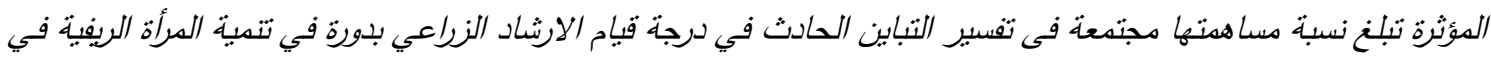

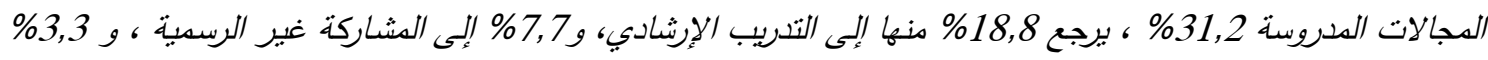

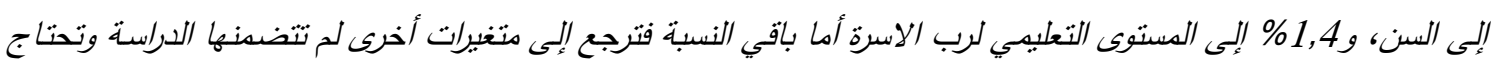

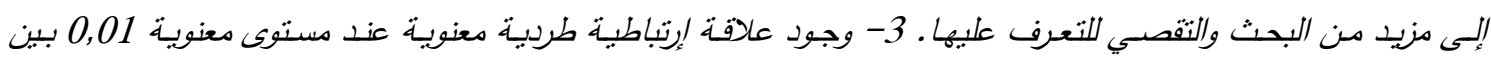

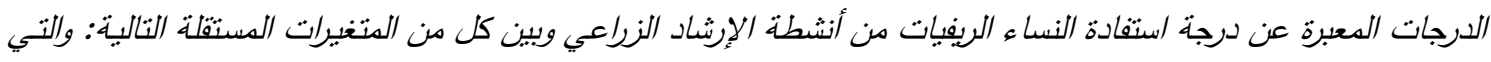

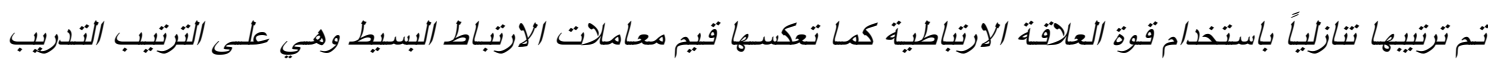

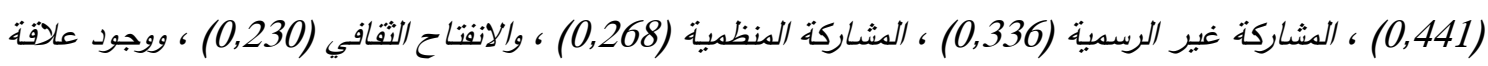

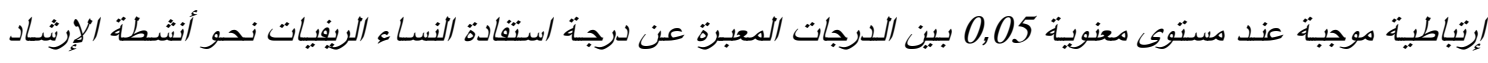

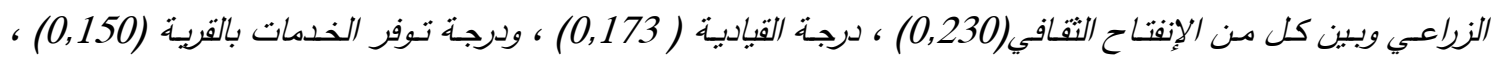

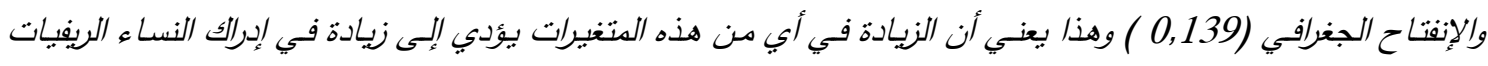

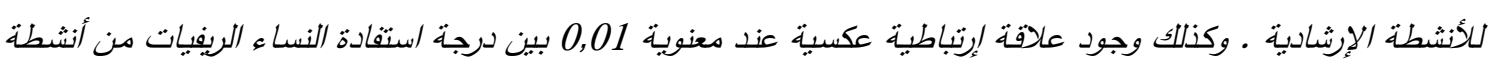

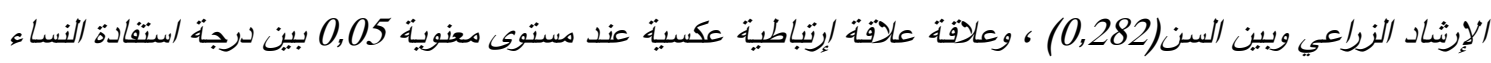

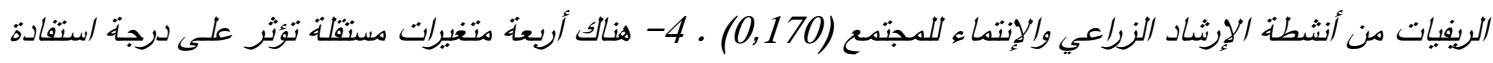

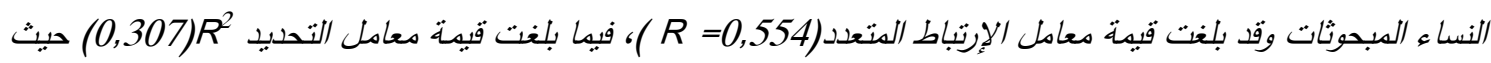

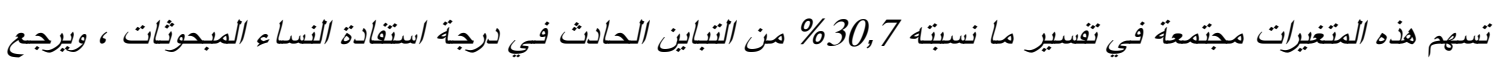

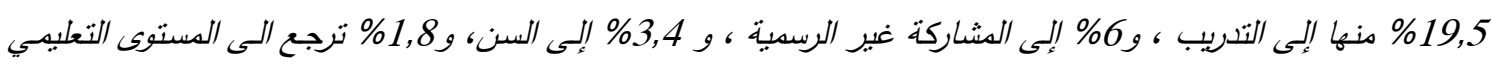

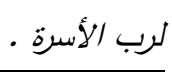

الغاية وهو الوسيلة.

فـالمحور الأساسـي في بـرامج التتميـة هـو المشـاركة البشرية للرجل والمرأة على السواء، وقد اتجهت الاهتمامات

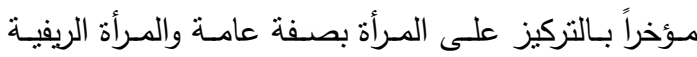

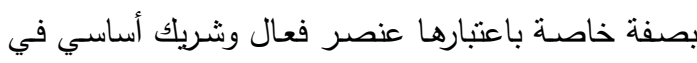

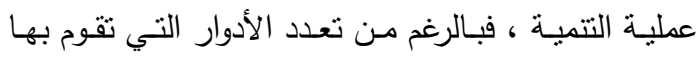

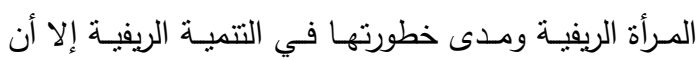

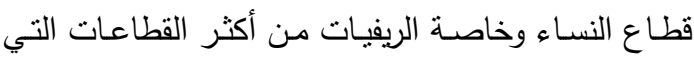
تحتاج إلى توفير العديد من برامج التعليم والتدريب والرعاية الصحية والإجتماعية وأيضاً نوفير المزيد من الأهتمام لهن لهن

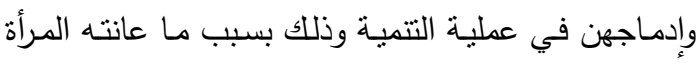
الريفيـة مـن الحرمـان لفترات طويلــة مـن أسـباب الرعايــة

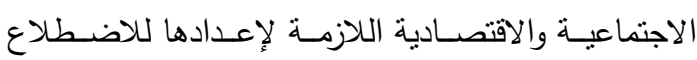
بأدوارها الفعالة في النتمية بالإضافة للاستفادة من عوائدها

\section{المقدمة والمشكلة البحثية}

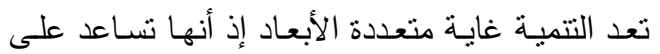
إحـداث تغييـرات في جميـع جوانـب الحيـاة الاقتصـادية

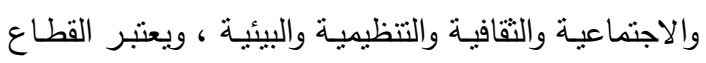

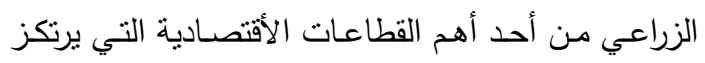
عليها إقتصاديات الكثير من الدول وخاصة الدول النامية،

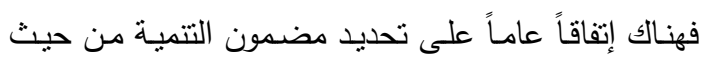

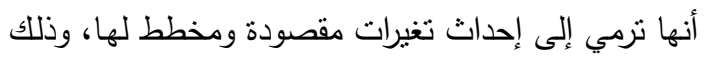

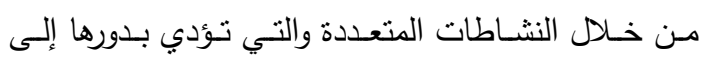
ضمان تدفق الإنتاج، وإحداث تراكمات متزايدة في الجوانب

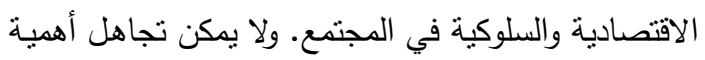

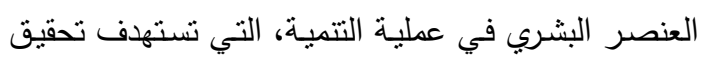

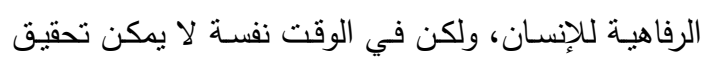

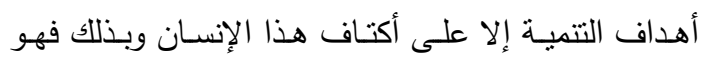


مشـكلات التتميـة في مجتمعنـا على مـدى ربـع القـرن

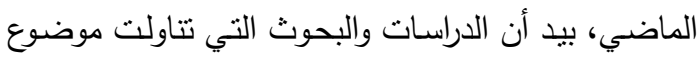
المرأة قد انصرف أغلبها إن لم يكن كلها على المستويين

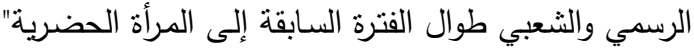
وعلى الأخص التي تشـارك بأجر في الأنشطة الإنتاجية

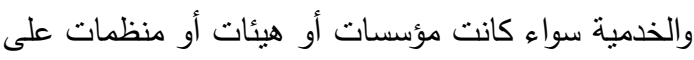
إختلاف أنواعها (غانم ، 1999).

أهداف الدراسة تسـتهدف هـذه الدراســة التنـرف علـى دور الإرشــاد الزراعي في تتمية المرأة الريفيه في بعض قرى محافظة

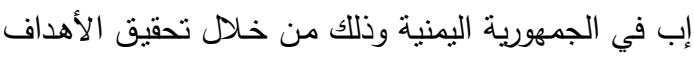
الفرعية والتي نسعى إلى التعرف على :

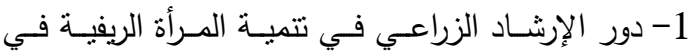
مجالات التتمية المدروسة.

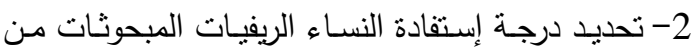
الأنشطة الإرشادية المدروسة.

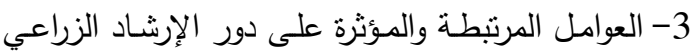
في تتمية المرأة الريفيه في مجالات التتمية الددروسة . 4- العوامل المرتبطة والمؤثرة على درجة إستفادة النسـاء الريفيات المبحوثات من الأنشطة الإرشادية . 5- المعوقـات التي تحـد مـن إسـتفادة النسـاء الريفيـات

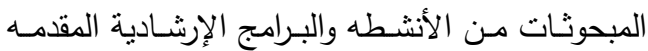
ل لهن

\section{الإطار النظري و الاستعراض المرجعي}

تمهيل : تتاول هذا الجزء مفهوم الدور ومكوناته ، المداخل النظرية في دراسة الأدوار التي تقوم بها المرأة في المجتمع،و الأدوار التي تقوم بها المرأة الريفية، ومن ثم لادئ

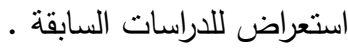

مفهوم الدور: أن الدور الاجتماعي من الدفاهيم الحديثة التي تعددت تعاريفها، فكما يذكر فرح أن الموسوعة الدولية للعلوم الاجتماعية حددت الدور بأنه نمط شامل للسلوك والاتجاهات، وأنه استراتيجية لمواجهة المواقف المتكررة،

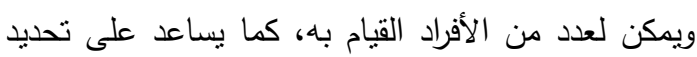

نظـراً لمـا تمتلـهـه مـن نسـبة كبيـرة في المجتهـع المحلي

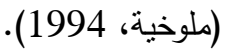

وقد أثـارت هدى الجنجيهي (1998) إلى أن جهاز الإرشاد الزراعي بمصر يستطيع إرشـاد المرأة الريفية من الفي ان

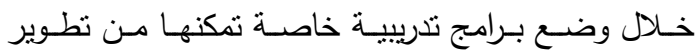
قدراتها فى الششاركة في أعمال زراعية وصناعية ريفية ثلية تؤدي إلى إرتفاع مستويات الإنتاج والدخل الزراعي.

ويسهم الارشـاد الزراعي بدور هام في التتمية الريفية بما يقدمه من برامج وأنشطة وخدمات إرشاديه لكافة الفئات

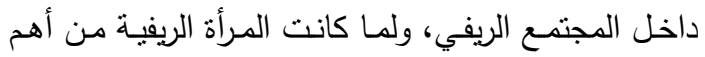
الفئات الموجوده في المجتمع بما يلقي عليها من اعباء بعد الفي هجرة الرجال، فالمرأة الريفية تقوم بأعمال تختلف بطبيعتها

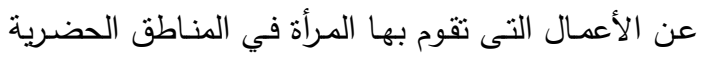
التي أتيح لها قدر كاف من التعليم وفرص العمل المناسبة

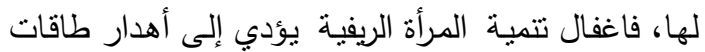

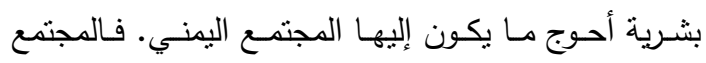

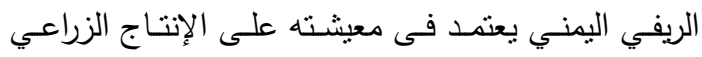

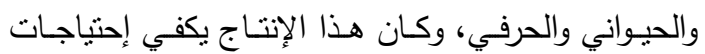

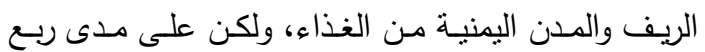

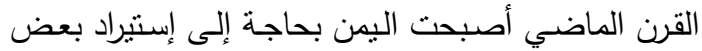

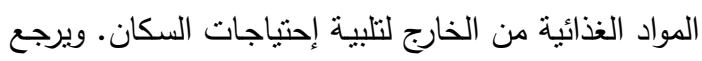
الإنخفاض في مستوى الإنتاج الزراعي والحيواني لعدة

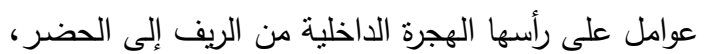

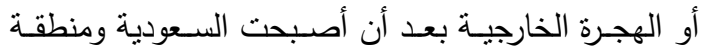

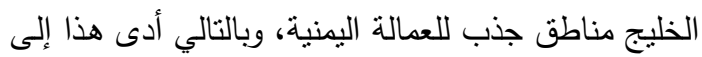

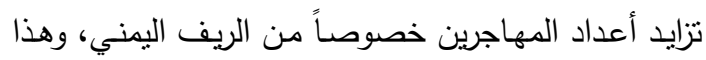
بدوره أدى إلى تحمل المرأة أعباء كثيرة منها تحمل مسؤلية الرئ اليني الإنتاج الزراعي في الوقت الذي قلت فيه الأيدي العاملة

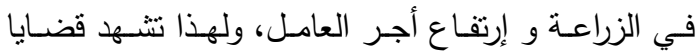

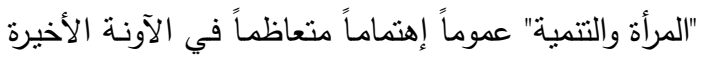

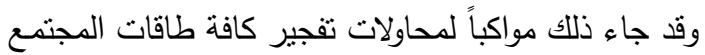
الينـي، وترشـيد أدوار مختلفـة لفئـات وشـرائح اجتماعيـة

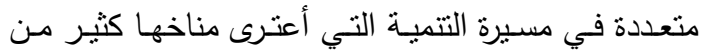

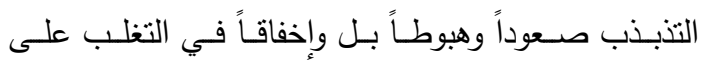


2- مدخل الثقافة : يذهب هذا المدخل إلى أن الأدوار

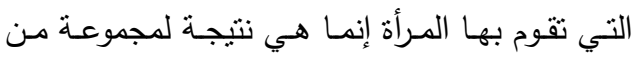

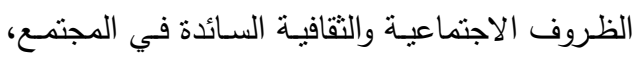

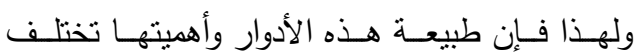
باختلاف المجتمع وتثافته.

3- المدخل الديموجرافي الجزئي : يتتـاول هذا المـدخل قضية المرأة من منظور الحجم الأمثل للسكان أي لئي يؤكد على بعد واحد هو البعد الكمي فقط من الأبعاد الديموجرافية ويصبح دور المرأة في ضوء تفسير هذا المدخل مرادفاً لنتظيم الأسرة فقط.

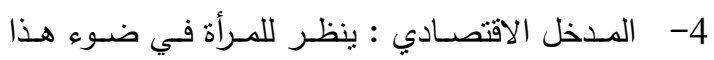

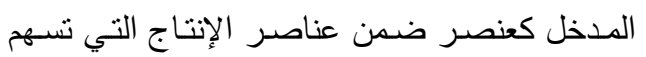
في مختلف الأنشطة ونولد الدخل القومي. ويلتقي الدـدل الاقتصـادي مـع المدخل المسادي في تفسير

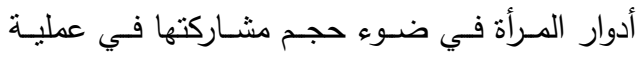
الإنتاج وتفسبر تدني مكانتها في ضوء فيامها فئ بأدوار هامشية في عملية الإنتاج. 5- مدخل التبعية : يمنل مدخل التبعية التحول من مفهوم

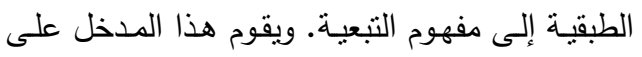
مفاهيم أساسية مثل السيطرة والاستقلال من الوحدات الأكثر نمواً للوحدات الأقل نمواً، ويقوم هذا المدخل في تفسيره لأدوار المرأة على افتراض أساسي مؤداه أن أسلوب الإنتاج الرأسمالي يحرص على لألى إيقاء المرأة كقوة عمل احتياطية.

\section{الأدوار التي تقوم بها المرأة الريفية}

تؤكد عفت عبدالحميد (1995) على أهميـة الـدور الـذي تلعبـه المـرأة فـي المجتمـع، وتؤكـد أن للمــرأة أدواراً

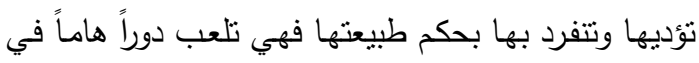

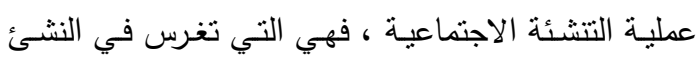
السلوك الاجتماعي المقبول والمطلوب معاً كما تساهم في الأنشطة الاقتصادية حيث يتفاوت دورها من نشـاط إلى الـى أخر ومن مستوى اقليمي لأخر كما أن المرأة مسئولة عن دون الأن الإنتاج الحيواني والداجني داخل المنزل ويزداد دور المرأة

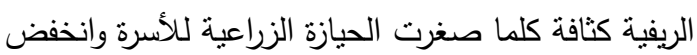

شخصية الإنسان ووضعه في المجتمع، لأنه مرتبط بالمطالب البنائية والاجتماعية وأفكار الثخص وضعه وسلوكه واهتماماته وقيم مجتمعه السائدة والمتغيرة، ويشير نفس الباحث أن بارسونز عرف الدور بأنه عملية تكتسب أثناء التنشئة الاجتماعية للأفراد، لذلك فأن تحليل الأدوار هام

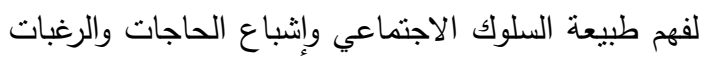

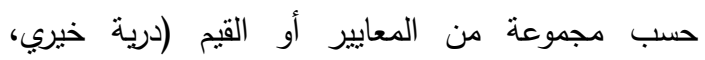
1999). ويذكر فهمي وعطية (2003) أن بارسونز يرى أن أداء الدور خلال الموقف الاجتماعي هو استجابة لتوقعات الاخرين وتحقيق للمعايير الاجتماعية ،واختلاف التاعب التابة

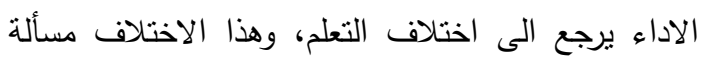

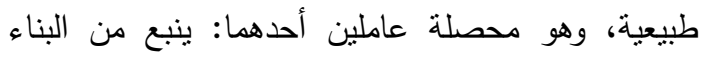
التتظيمي وتحدده مطالب الأدوار والجزاءات الاجتماعية، والاخر يعبر عن صفات وتصورات الفرد عن الدور، وأن الجناءن كل سلوك للاور له واقع برتبط بنسق القيم وتوقعات الأدوار ويهدف الواقع لتحقيق الاثشباع من خلال أداء الدور . مكونات الدور : يذكر إسماعيل (2005) نقلا عن غنيم وقناوي بأن مكونات الدور تتضمن الأتي:

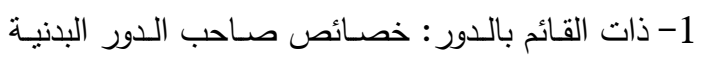
والنفسية المنعلقة بالمركز الذي يشغله.

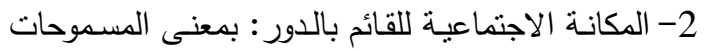
والممنوعات الموكلة اليه كثيء منضمن في مركزه.

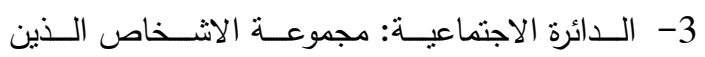

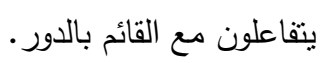
4- الوظائف الاجتماعيـة للقائم بالدور :مدى إسـهامه مـع باتئح الأشخاص في الدائرة الاجتماعية. المداخل النظرية في دراسة الأدوار التي تقوم بها المرأة في المجتمع تذكر درية خيري (1999) نقلا عن إبتهال ابو حسين

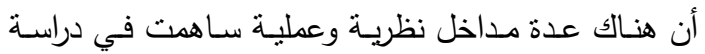
أدوار المرأة منها:

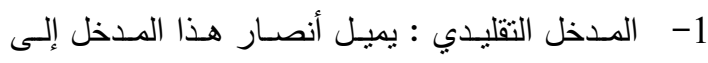

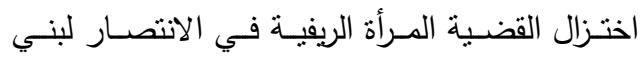
جنسها والدفاع عن كيانها النسائي، واعتبار العمل العل والإسهام الاجتماعي تعبيرا عن نبذ التبعية للرجل. 
والمنزلية. ويشير محرم (1990) أنه بالإضـافة الى دورها الاقتصادي المركب في الاستهلاك والادخار العائلي، فإنها

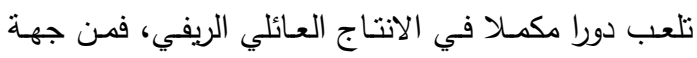
تسـاعد كثير من النسـاء الريفيات لرجالهن في الاعمـال

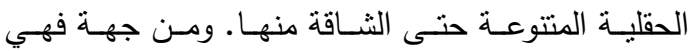

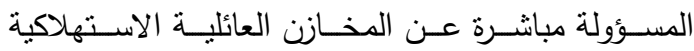

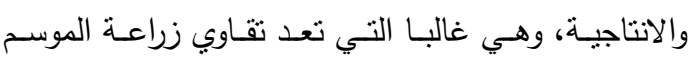

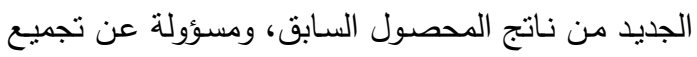

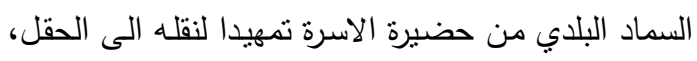
وأيضـا تقـوم بالجهـد الغالب لإعـداد المخلفـات النباتيــة

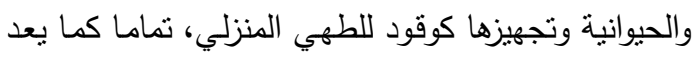
الانتاج الحيواني الصغير من مسؤولياتها الرئيسية خاصـة ولئه

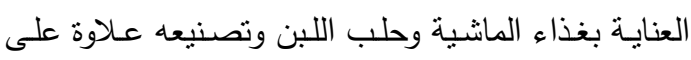
احتكارها الاشراف على الانتاج الداجني العائلي.

ثالثاً: دور المرأة في الصحة الإنجابية وتتظيم الأسرة :

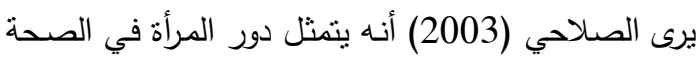

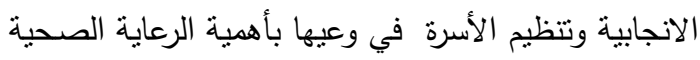

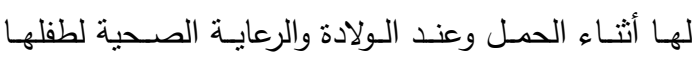

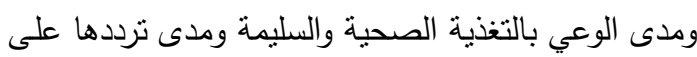

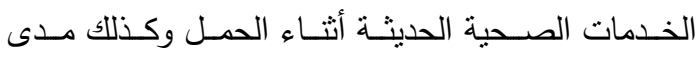
تفضيلها لمكان ولادتها بين الأسرة أو المركز الصحي أو أولئ

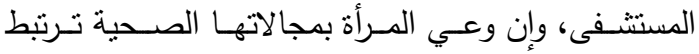

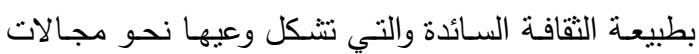
الصحة الإنجابية وتتظيم الأسرة، فإذا كانت النساء الريفيات

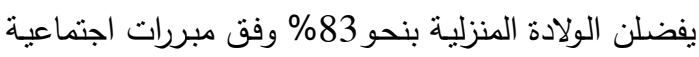
وثقافية وكذلك وفق مبررات اقتصادية (الفقر) فإن المبررات

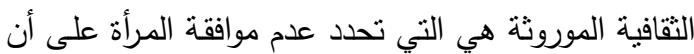

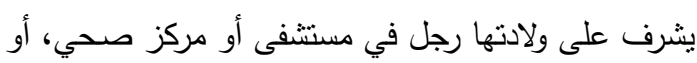

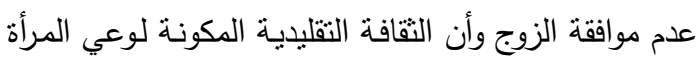

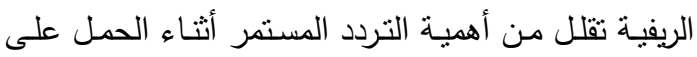
الاستشـارات الطبية الحديثة، ومي ذلك فالنسبة تنزايد بين الفردين النسـاء اللاتي يفضلـن الولادة في المستشفيات والمراكز الصحية 15\% كل ذلك لا يرتبط فقط بجهل المرأة وأميتها

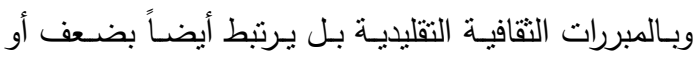

دخلها واعتمدت على العمل العائلي غير مدفوع الأجر.

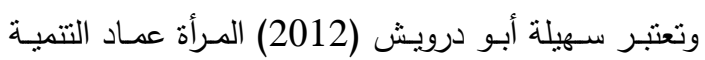
الريفية وتطوير المجتمع الريفي نظراً لمساهنتها الحيوية في لمئي

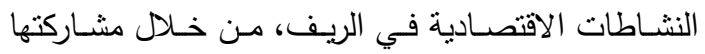

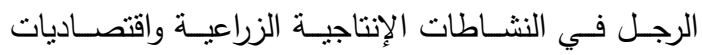

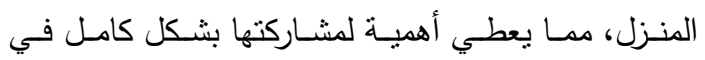

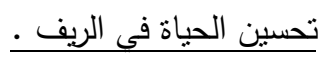
اولاً: دور المـرأة في المنزل والتتشـئة الاجتماعيـة: يـرى

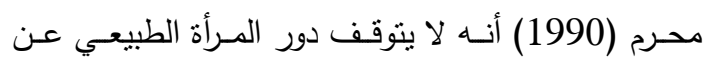
مجرد انجاب كائن بشري حي لحظة الميلاد، بل انه يمتد تلقائيا لفترة رعاية لصيقه للرضاعة لمدة تصل الى عامين

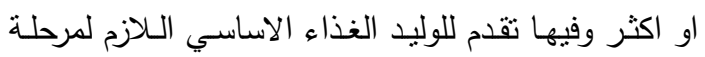

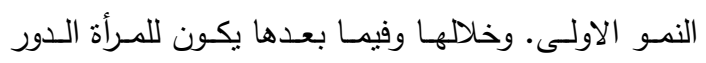

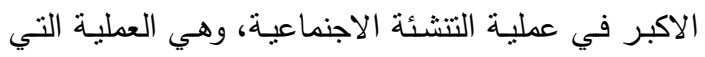

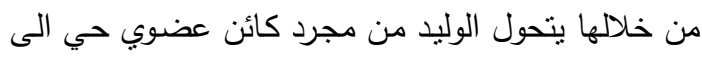

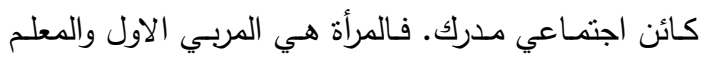

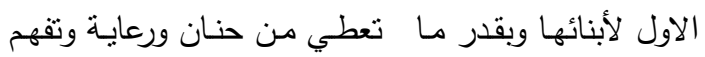

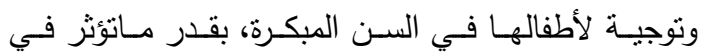

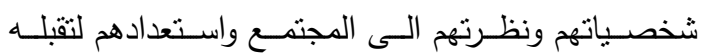

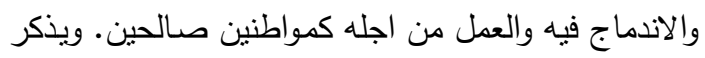

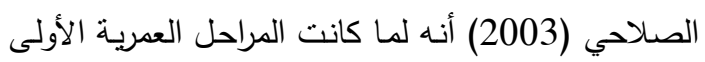
للطفل ذات أهمية في تتشئته فإن وعي الولد والفتاة بيدأ

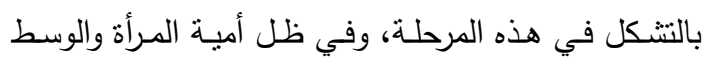

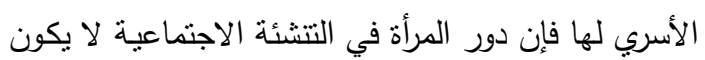
داعمـاً للتطـور والتتميـة مـن خـلال دعمهـا لتعليم الفتـاة وتجديد نشاطاتها الإنتاجية ومن حيث تأخير سن الزواج ومن حيث وعيها بأهمية تتظيم الأسرة والصحة الإنجابية.

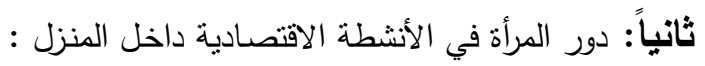
تذكر عفت عبد الحميد (1990) انه بجانب الدور الكبير الذي تقوم بـه المرأة الريفية في مساعدة زوجها في العمل

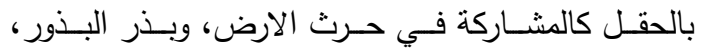

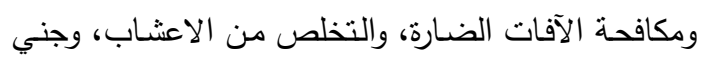

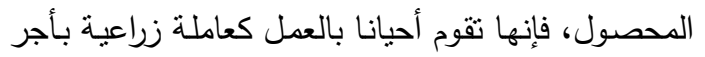
أو لحسابها في فلاحة الحدائق أو بيع المنتجات الزراعية 
الحقلية، ومن جهة أخرى في المسئولة مباشرة عن المخازن

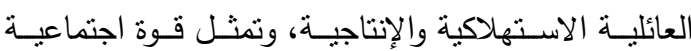
مستترة فالغالبية العظمى من الهتمعات المعاصرة وخاصة الريفية يقوم الرجل رب الأسرة بتمثيل أسرته أمام المجتمع

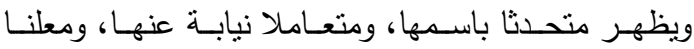
لقراراتها الاجتماعية و الاقتصادية.

سادساً: دور المرأة في تحقيق الأمن الغذائي: تذكر المنظمة العربية للتتمية (2010) أن المرأة تشكل مصدراً رئيساً في النتمية الزراعية والأمن الغذائي في الوطن النيات العربي حيث يثكل سكان الريف في الوطن العربي حوالي

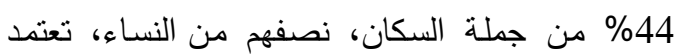

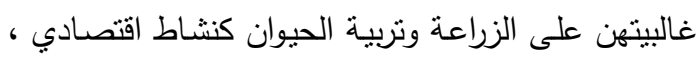
وتعمل المرأة العربية الريفية قرابة الثمانية عشر ساعة يومياً، فهي أول أفراد الأسرة استيقاظا في الصباح الباكر الخربة

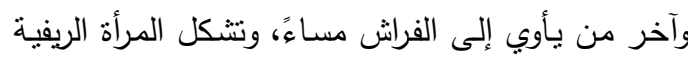

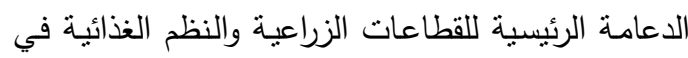
العديد من الدول العربية التي يتفرغ فيها الرجال لمهام

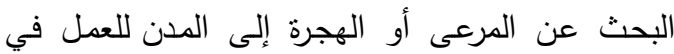
قطاعات الاقتصاد الأكثر إدرارا للاخل فنتولى المرأة العناية

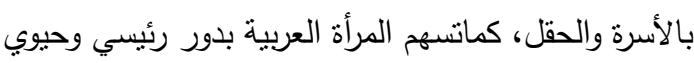
في الأمن الغذائي الأسري، ومن ثم الوطني، وذللك من

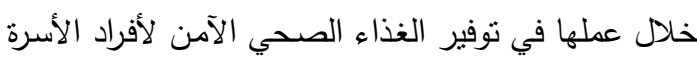
وحسن إدارة الدخل والاقتصاد في استهلاك الغذاء.

\section{الاراسات السابقة}

لقد تم الاطلاع علي (15) دراسة ذات صلة وتم تصنيفهن الى ثلاث مجموعات رئيسية وهي على النحو

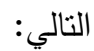

اولاً: الدراسات التي تناولت دور المرأة في التنمية دراسة غانم (1999) وتتاولت إلقاء الضوء على دور

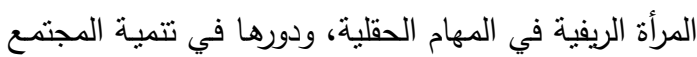
الريفي، وزيادة دخل الاسرة، و تحديد المشاكل والمعوقات التي تتعرض لها المرأة. ووجدت الدراسة أن 95,2\% من

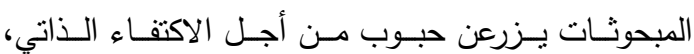

غياب الخدمات الصحية في عموم الريف اليمني إضـافة إلى نزايد كلفتها المادية.

رابعاً: دور المرأة الريفية في الانشطة الزراعية

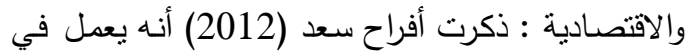

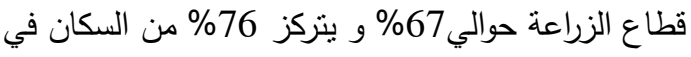
المناطق الريفية تقطن 80\% منهم في تجمعات سكانية لا لاعل

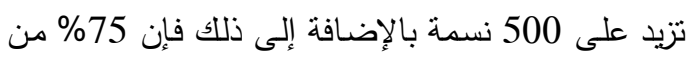
فقراء اليمن يعيشون في المناطق الريفية، و 88\% من بن النساء لهن نشاط اقتصادي في الإنتاج الزراعي مقابل

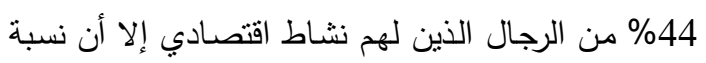
83 منهن بعملن بدون أجر ولا يحتسب لهن ساعات

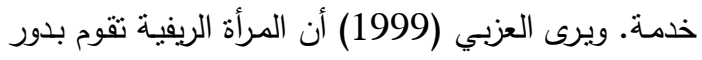
كبير في مساعدة زوجها في العمل بالحقل، كالمشاركة في

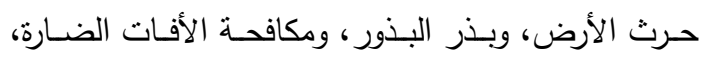

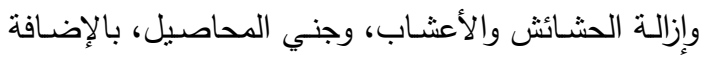

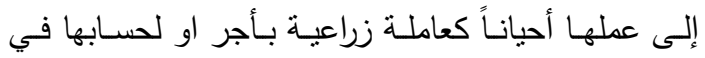

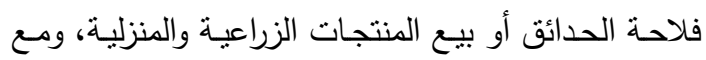

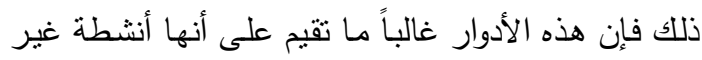
إنتاجية نظراً لأنها لا تحصل في الغالب عالب ملى أجر نقدي مقابل ذلك. خامساً: دور المرأة الريفية في التسويق: تذكر أفراح سعد

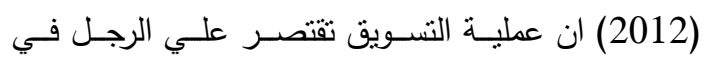

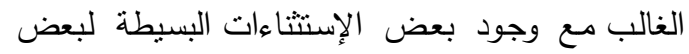

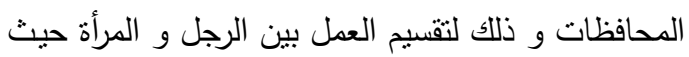

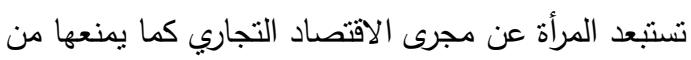

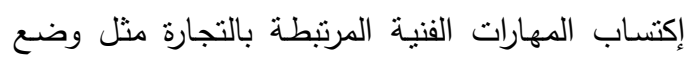
الموازنة و المساومة و كذا التوفير • في حين يرى محرم (2004) أن المرأة تلعب دور اقتصادي يظهر في ترشيد الاستهلاك أو زيادة المدخرات العائلية ومن ثم الاجتماعية بما يتيح فرصا أوسع للاستتمار وخلق الطاقات الإنتاجية الجديدة في المجتمع، كذلك تعد قوة إنتاجية متتامية حيث تقوم المرأة في المشـاركة في العملية الإنتاجية فمن جهة تنساعد كثيـر مـن النسـاء الريفيـات الرجـال في الأعمـال 
المجالات ودور المرأة الريفية ، ووجد أن الأبعاد التالية

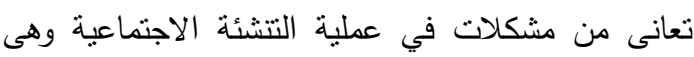
على النرتيب: بعد الدطالبة، يليه بعد التفرقة، ثم التوجيه، ثم الثواب ثم التأديب، ثم الرعاية والتحكم ثم العقاب ثم

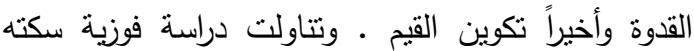

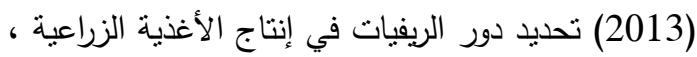

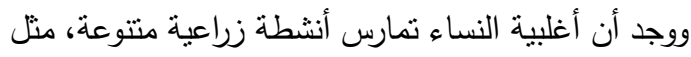

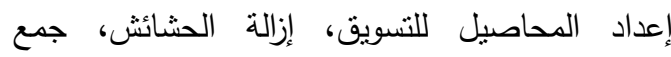
المحصول .كما تساهم النساء في مختلف أنشطة الإنتاج الحيواني مثل تربية الدواجن، ورعاية حيوانات الحظائر . كما تنين أن 98\% من المبحوثات يمارسن التدبير

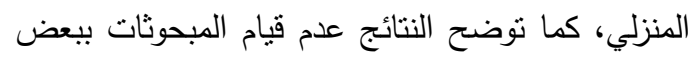
المهام الزراعية، كتجهيز الأرض للزراعة، وزراعة البذور

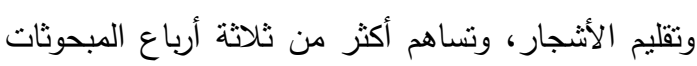
89 في مختلف الأنشطة، وبالنسبة إلى الدور الانتاجي للمرأة في مجالات غير زراعية نقل نسب المبحوثات

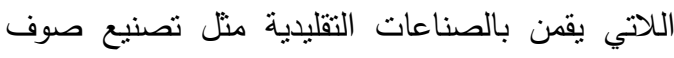
الأغنام 19\% من أجل تتمية الدخل الاسري. وتتاولت دراسة هبه محمود (2013) التعرف على دور المرأة الريفية في التتمية المستدامة من حيث التعرف على دورها

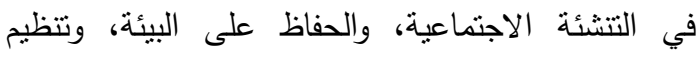
الاسرة، والمشاركة السياسية واخيراً دورها في الانتاج

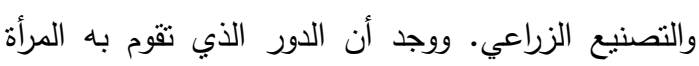
الريفية دور حقيقي ومؤثر في التنمية المستدامة، وبالنسبة التراعية لدور المرأة في النتشئة الاجتماعية فقد بينت نتائج الدراسة فئة الدئة

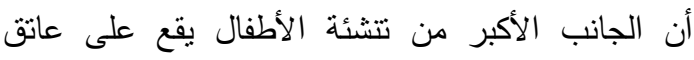

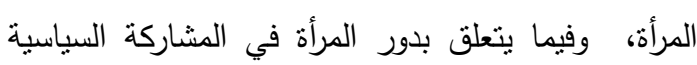
وجد قصور في مختلف النواحي المتعلقة بمدى ممارسة بلدية

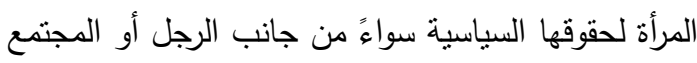

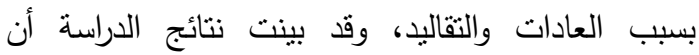
الانفتاح الثقافي والجغرافي، والدكانة الوظيفية لعمل المرأة،

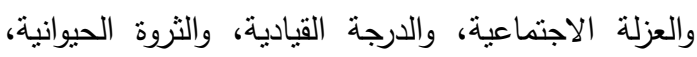

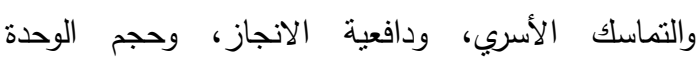

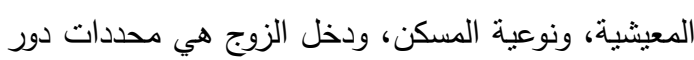

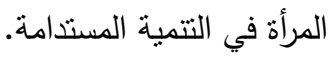

وبالنسبة لمساهمة المرأة الريفية في أنشطة الإنتاج الزراعي

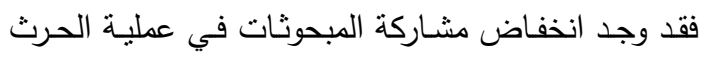

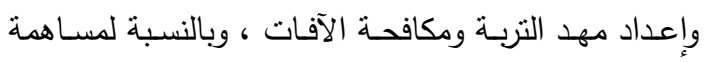

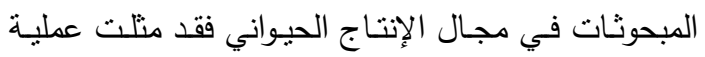

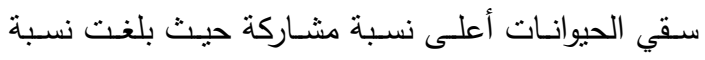
المشاركة حوالي 67\%، يليها عملية تربية الدواجن والطيور حيث بلغت نسبة المشاركة 66\% و تناولت دراسة هدى خليفة (2003) التعرف علي

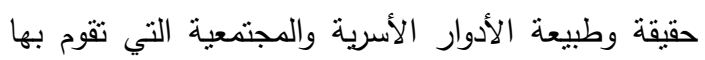

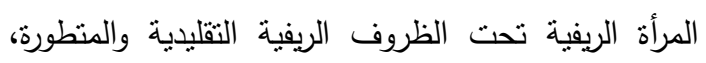
والوقوف علي أهم العوامل المرتبطة والمحددة لأداء المرأة

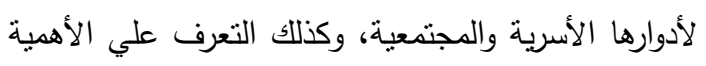
النسبية لكل من هذه العوامل • وتناولت دراسة آمال موسى، ونادية زكي (2006) التعرف على درجة قيام المرأة الريفية بدورها في انتاج وتداول اللبن النظيف، وسبل

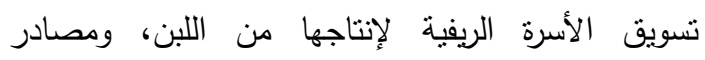

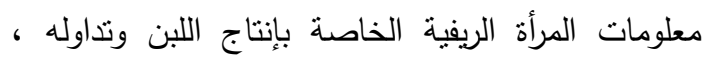
ومعنوية العلاقة بين بعض خصائص المبحوثات وبين

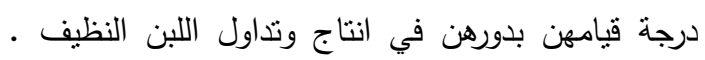
وبينت النتائج ارتفاع مستوى أداء الريفيات الدبحوثات فئات

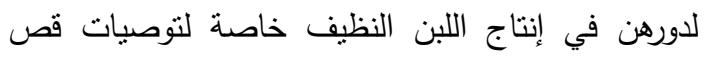

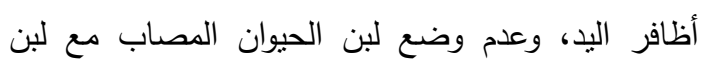

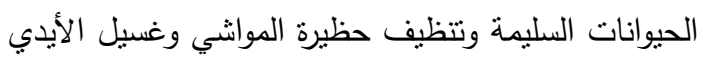
وتتشيفها جيداً، وكذلك وجود علاقة ارتباطية طردية بين

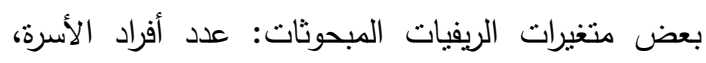
وحيازة حيوانات اللبن ،والقيادية، ودرجة قيامهن بدورهن في الفئي

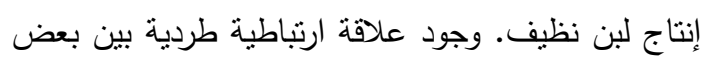

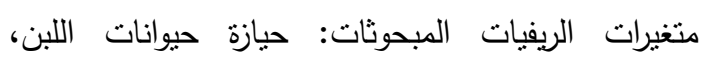
والقيادية، وكمية اللبن التي يتم انتاجها، والمسافة بين مكان الانتاج والتنسويق درجة قيامهن بدورهن في تداول اللبن لتين النظيف. وتتاولت دراسة دراسة مي الإمام (2008) اختيار

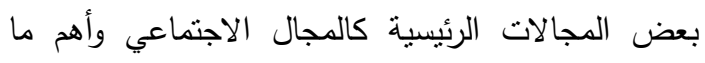

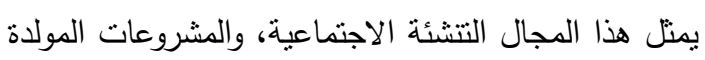
للاخل كأبرز الأدوار الاقتصادية والمشاركة السياسية للمرأة

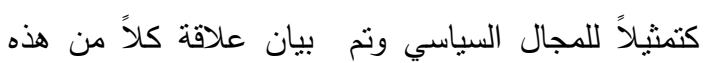


والتعرف على العلاقة بين تلك المتغيرات وكل من المتغيرات المستقلة موضع الدراسة. ووجد من نتائج الدراسة أن نحو 44,5 \% من إجمالي المبحوثات استفدن بدرجة منوسطة من التدريب، ونحو 57,4\% منهن تحسنت مهاراتهن من خلال برامج التدريب بدرجة كبيرة، كما تبين أن نحو 45,8 \% من إجمالي المبحوثات راضيات بدرجة

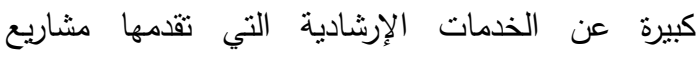
الاستيطان الزراعي من خلا مراكز التتمية الريفية، واتضح وجود علاقات ارتباطيه معنوية بين درجة استفادة المبحوثات من برامج التنريب وبين كلا من المتغيرات

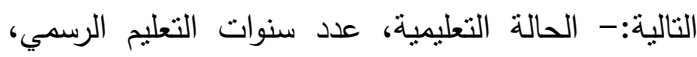

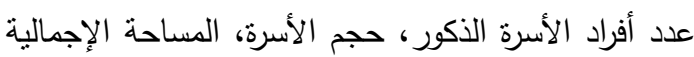

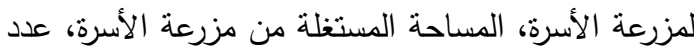

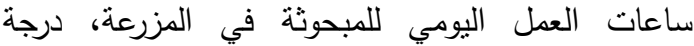
التعرض لمصادر المعلومات الزراعية، مدة التدريب بمراكز التتمية الريفية، درجة أهمية البرامج التدريبية، كما تبين وجود علاقات ارتباطيه معنوية بين درجة تحسن المهارات من خلال برامج التدريب، وبين كل من المتغيرات النالية: العمر ،عدد ساعات العدد اليومي للمبحوثة في المزرعة، درجة التعرض لمصادر المعلومات الزراعية، درجة أهمية البرامج التدريبية، كذلك وجود علاقات ارتباطيه معنوية بين درجة ملائمة ظروف التدريب للمبحوثات وكل من: عدد ساعات العمل اليومي للمبحوثة في المزرعة، وعدد مرات

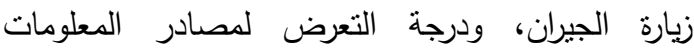

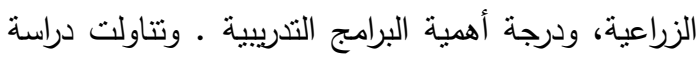
الجمل (2013) التعرف على فعالية ثلاث طرق إرشادية مختلفة (الاجتماعات الارشادية، الاتصالات التلفونية،

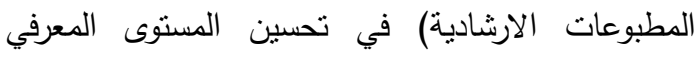

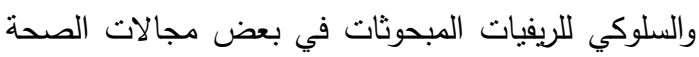
الاسرية، واظهرت النتائج فيما يتعلق بالاحتياجات الإرشادية للريفيات المبحوثات في مجال الصحة الاسرية فقد جاء مجال الوقاية من الامراض في الترتيب الاول من الإناله

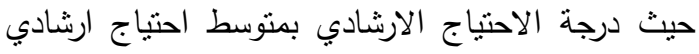

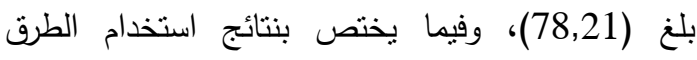

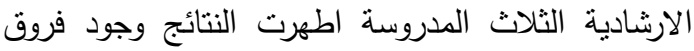

ثانياً: الدراسات التي تناولت دور الإرشاد الزراعي في تثمية المرأة

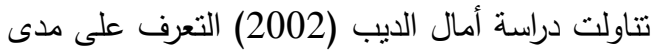

إدراك الريفيات للأنشطة الإرشادية التي يقدمها جهاز

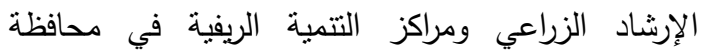
الدراسة، تحديد درجة استفادتهن من هذه الأنشطة، والتعرف على طبيعة ودرجة اتجاة الريفيات نحو الإرشاد

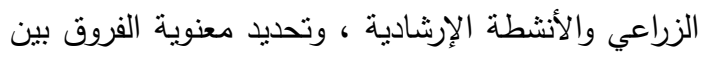
المبحوثات في محافظة الدراسة من حيث إدراكهن واستفادتهن واتجاههن نحو الأنشطة المقدمة لهن، والتعرف على المشاكل والمعوقات التي تحد من استفادة الريفيات من الأنشطة والبرامج الإرشادية الموجهة لهن لوبينت الدراسة وجود علاقة معنوية بين درجة إدراك المبحوثات للأنشطة الإرشادية وخمس متغيرات من المتغيرات المستقلة وهي عمر المبحوثة، المستوى المعيثي ،والاتصال الثخصي بالمرشدة الزراعية، والتذريب ،وعمل المبحوثة

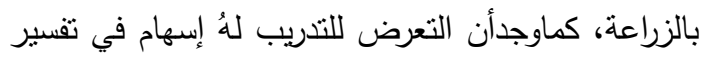
التباين الكلي بين المبحوثات من حيث إدراكهن وكذلك استفادتهن واتجاههن للأنشطة الإرشادية، وبينت النتائج احتياج المبحوثات الي ارشادهن في المجالات التالية هي الصناعات الريفية الغذائية، والصناعات البيئية والحرفية،

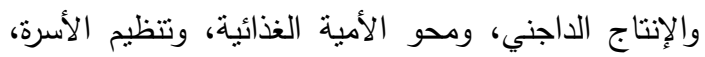

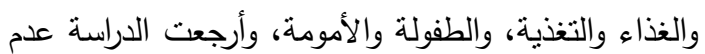
استفادة المرأة الريفية من الأنثطة الارشادية الي سببين

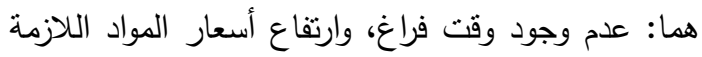
لتطبيق بعض الأنشطة. وتتاولت دراسة السبيعي (2009) التعرف على الدور

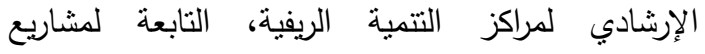
الاستيطان الزراعي بالجماهيرية الليبية، واستكثاف نتائج انترالك المبحوثات في برامج التنريب بهذه المراكز فيما يتعلق بدرجة استفادتهن، وكذللك تحسن مهاراتهن في مجال الزراعة، ودرجة ملائمة ظروف التدريب لهن، ودرجة وجود معوقات في برامج التنريب، وكذلك درجة رضاهن عن الخدمات الإرشادية التي تقدم من خلال هذه المراكز، 
ودرجة الاتصال بالطبيب البيطري، حيث تفسر 33\% من التباين الكلي في معدل الاحتياج الإرشادي ـ وكانت اهم

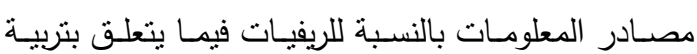
الدجاج هي: الأهل، الاقارب، والخبرة الثخصية. وتتاولت دراسة الصباغ (2005) التعرف على الخدمات التي تقدم للمبحوثات بمنطقة الدراسـة، والتعرف علي درجـة استفادة ورضـا المبحوثنات عن الخدمات والأنثطة المقدمـة لهن بمنطقة الدراسـة، والتعرف علي درجـة مسـاهمة المتغيرات المستقلة المدروسة في المتغيرات التابعة والوسيطة، التعرف علي أهم المشكلات التـي تواجـه المبحوثـات مـن وجهـه نظرهن بمنطقه الدراسة، وتحديد الاحتياجات التتموية للمرأة الريفية (بمنطقة الدراسة) من وجهه نظرهن، ووضع نموذج مقترح يتضـمن اسـتراتيجية لكيفيـة ســ احتياجـات الكـرأة الريفية في الواحـات البحريـة ـ واوضحت النتائج أن نحو

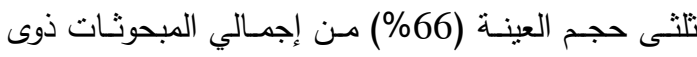
احتياج متوسط من الخدمات الصحية ، بينما بلغت نسبة الهبال المبحوثات ذوى الاحتباج الصحي المرتفع نحو 28,8\% ، وأثنـارت النتـائج الـى ان نحسو 60,2\% مــن إجمــالي المبحوثات ذوى احتيـاج منوسط من الخدمات التعليمية ، بينما بلغت نسبة المبحوثات ذوى الاحتياج التعليمي المرتفع نحو 15,9\% من إجمالي المبحوثات،كما أثنارت النتائج الى ان نحو 31,9\% من إجمالي المبحوثات ذوى احتياج

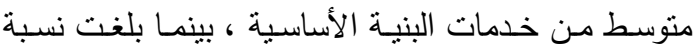
المبحوثات ذوى الاحتباج المرتفع من البنية الأساسية نحو

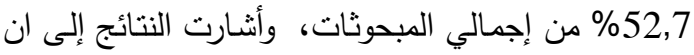
نحـو 69,2\% ذوى احتيــاج متوسـطـ مـن المشـروعات

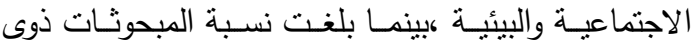
الاحتياج المرتفع من المشروعات الاجتماعية والبيئية نحو $\% 17,3$

وتتاولت دراسـة فتحيـة عارف (2010) التعرف علي

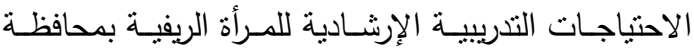
الإسماعيلية لبعض المجالات التدريبية الزراعية من خلال تحديد درجة الاحتياج التدريبي للمبحوثات وفقا لتقديرهن

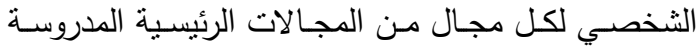

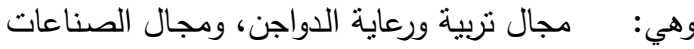

معنوية بين مستوى معارفهن وسلوكياتهن قبل وبعد التعرض للطرق الارشادية الثلاث الددروسة. وتتاولت دراسة حسين، هنادي ميرغني (2013) إمكانية نطبيق المفاهيم الإرشادية وبالتالي زيادة الإنتاج بالمنطقة وأهية إنشاء وحدات إرشادية لجمع البيانات لتقديم الخدمات

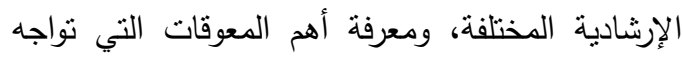
المرشدون بالمنطقة وإيجاد الحلول لها. واوضحت نتائج الدراسة|رتفاع نسبة الأمية وافتقار المنطقة لوجود مكتب وضعف تطبيق البرامج الإرشادية الخاصة بتتمية المرأة . وقد بينت الدراسة أن ضعف تطبيق متل هذه البرامج

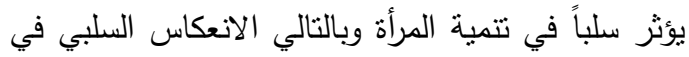
تحقيق النتمية الريفية والمتوازنة بمنطقة الدراسة. في حين أظهرت أهم نتائج الدراسة التأثير السلبي للعادات والتقاليد

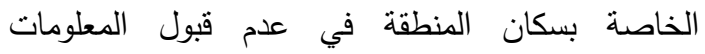
الإرشادية وتتفيذها وبالنالي قلة الإنتاج وعدم إمكانية تحقيق أبعاد تتموية، كما توصلت الدراسة إلى عدد من المشكلات

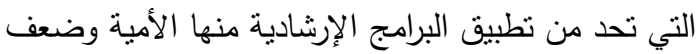
بيئة العمل وضعف المشاركة المجتمعية.

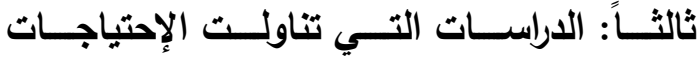
الإرشادية للمرأة

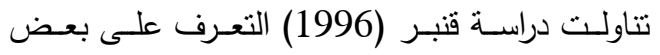

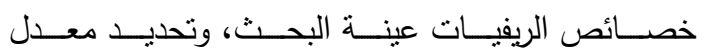
الاحتياجات الإرشادية المعرفية والتتفيذية للمرأة في مجال تربية الدجاج، ثم تحديد علاقة الاحتياجات الارشادية للمراة الريفيـة في مجـال تربيـة الدجاج والمتغيرات المدروســة . وتمتلت اهم النتائج بوجود علاقة معنوية طردية بين معدل الاحتياجات الارشادية للمرأة الريفية في مجال تربية الدجاج

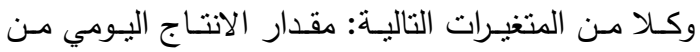
البيض، المشاركه الاجتماعية غير الرسمية، العمر، مقدار

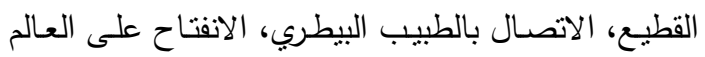
الخارجي، والاتجاه نحو التحديث،وجود علاقه معنوية بين معدل الاحتيـاج الارشــادي وكـلا مـن المتغيـرات التاليـة:

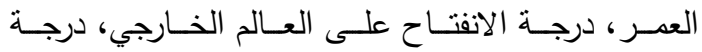

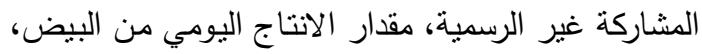


الدراسة إلى أن النشرات الارشادية، ومديرية الزراعة،

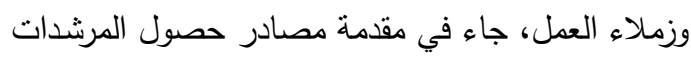

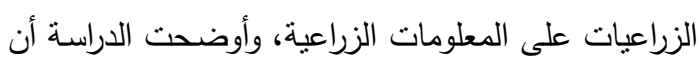

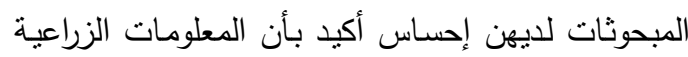

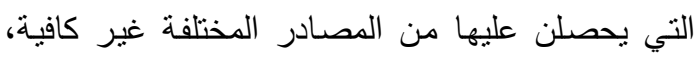

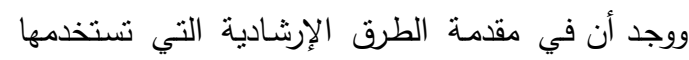

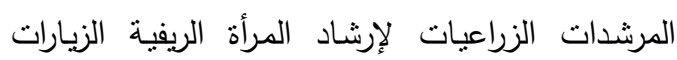

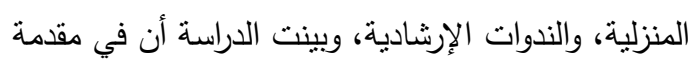

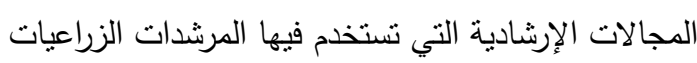
الطرق الإرشادية لإرشاد الريفيات تتظيم الأسرة، وتربية ورعاية الدواجن، ومحو الأمية.

وتتاولت دراسـة شيرين الديب (2016) التعرف علي

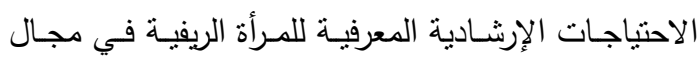
إنتاج لبن نظيف وآمن ببعض مراكز محافظة كفر الثيخ.

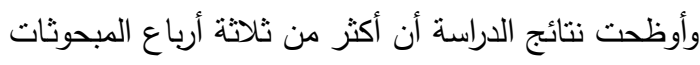

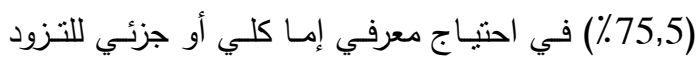

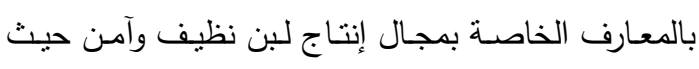

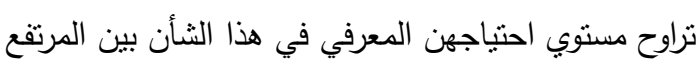

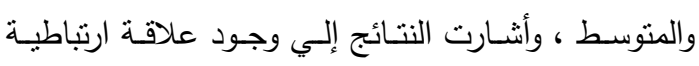

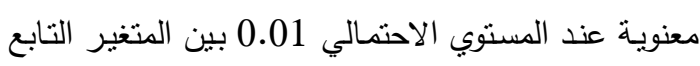
وهو درجة الإحتياجات المعرفية للمبحوثات في مجال إنتاج

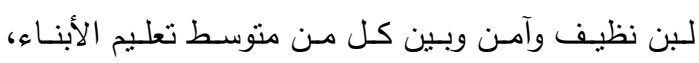
والحيازة الزراعية، والمساحة المزروعة بالأعلاف ، والحيازة

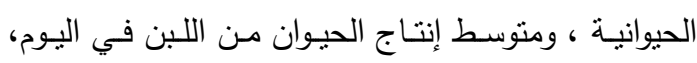

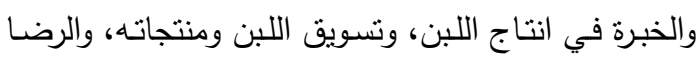

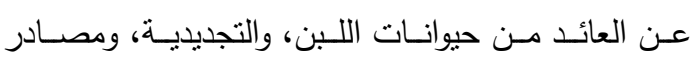
المعلومات، والاتصال البيطري، في حين لم توضح النتائج

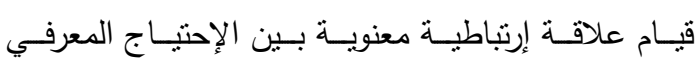

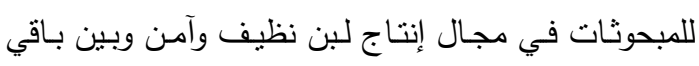

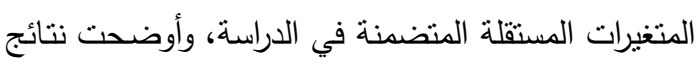

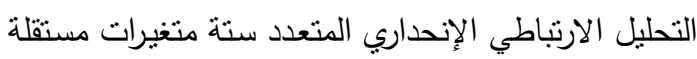

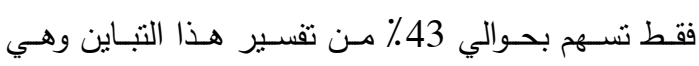
الاتصال البيطري وتسويق اللبن ومنتجاته، ومنوسط إنتاج

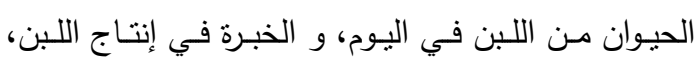

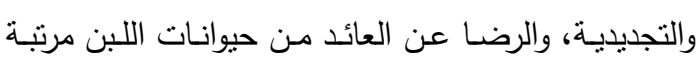

الريفيـة، ومجال إنتاج المحاصيل الزراعية، ومجال جمع

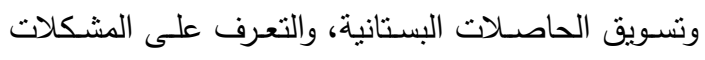

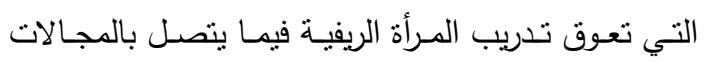

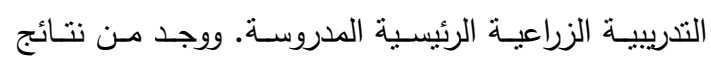

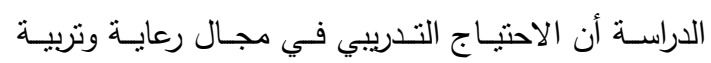
الدواجن كاحتياج تدريبي عالي يليه الاحتياج التدريبي في لتي

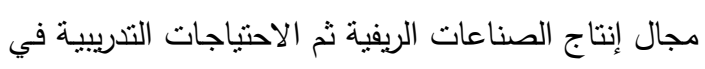

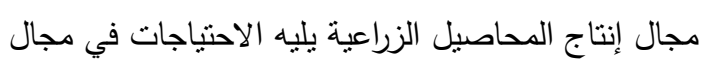

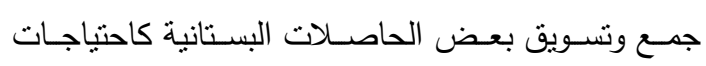

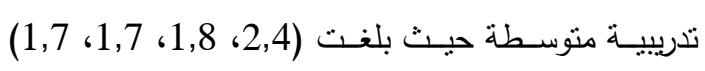

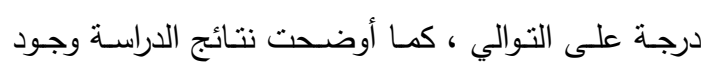
علاقة ارتباطية طردية معنوية عند مستوي معنوية $(0,01)$ بين حجم الحيازة الزراعية للأسرة ومجال إنتاج الدحاصيل

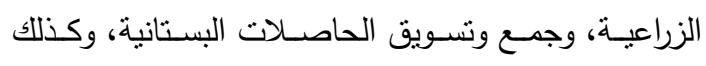
وجود علاقة ارتباطية عكسية معنوية عند مستوي (0,01) بين السن ومجال الصناعات الريفيـة غير الغذائيسة، كمـا توجد علاقة ارتباطية عكسية معنوية عند مسنوي $(0,05)$ بين درجة الاستفادة من المصادر التي تستقي منها المرأة الريفيـة معلوماتهـا ومجــالي الصـنـاعات الريفيـة الغذائيــة

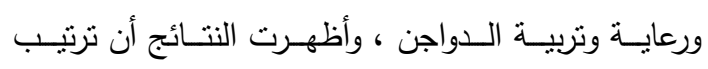

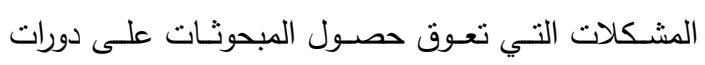
تدريبية كانت على النحو التالي : عدم وجود أندية نسائية

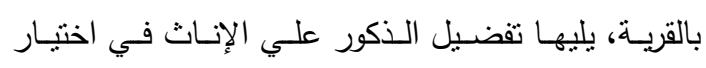

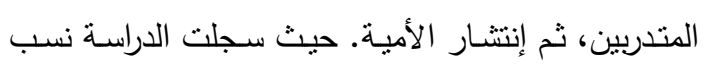

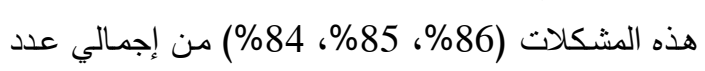

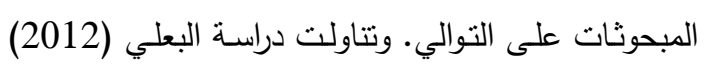
التعرف على واقع إرشاد المرأة الريفية في محافظة الغربية

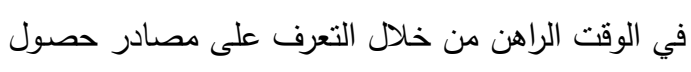

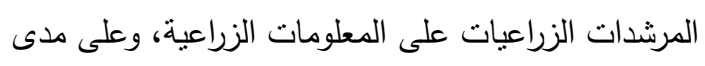

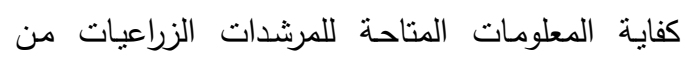

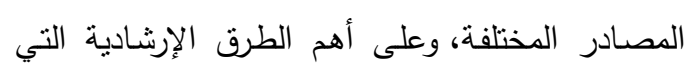

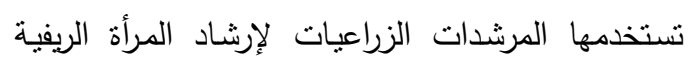

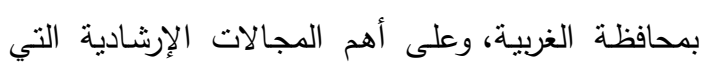

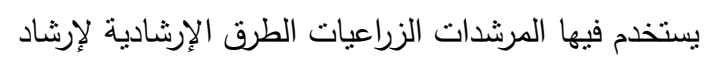

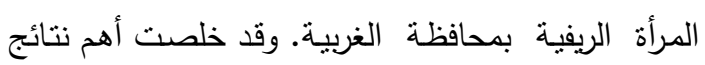




\section{الفروض النظرية}

الفرض النظري الاول : نؤثر المتغيرات المستقلة المدروسـة

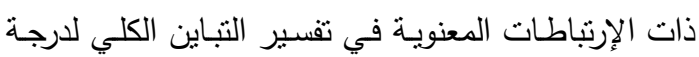
قيـام الإرشـاد الزراعي بـدوره في تتميـة المـرأة الريفيـة في

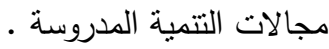

الفرض النظري الثاني: تؤثز المتغيرات المستقلة المدروسـة ذات الإرتباطات المعنويـة في تفسير التباين الكلي لدرجـة استفادة النساء الريفيات المبحوثات من الانشطة الارشادية التي يقدمها الارشاد الزراعي.

\section{الإجراءات البحثية}

اولا : منطقة الدراسة واختيار العينة

أجريت هذة الدراسة بمحافظة إب في الجمهورية اليمنية وذلك لأنها من المحافظات الزراعية في الجمهورية اليمنية، وتتضمن مستويات اجتماعية وحضارية وثقافية مختلفة مما ساعد على أن تكون العينـة المختارة من مجتمع الدراسـة عينة ممنلة لها في جميع الصفات والخصائص إذ اختيرت العينة من مناطق مختلفة من المحافظة. وقد اختير لإجراء هذه الدراسة عدة قرى شملت : 1- مديرية السياني وشملت عزلة النقلين واختير منها قري

$$
\text { (الجرذم و رقاد و ذي المحمر). }
$$

2- مديريـة بعدان وشـملت عزلـة الدعيس و واختير منهـا

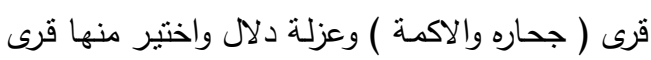

$$
\text { • (العلهه ومسوره واربان) }
$$

3- مديرية العدين وشملت عزلة الساره واختير منها قرى (الكرب ) وعزلة الجبلين شملت قرى (الروس و الرابط

$$
\text { و الشعوبة) م }
$$

4- بمديريـة جبلـة وشــت عزلـة وراف واختير منهـا قرى (ذي عقيـب والكريـف ) وعزلـة الجبلـين شـملت قرى (الـروس و الـرابطـ و الثـعوبـ) . وتـم اختيـار عينـة عشوائية بسيطة بنسبة 15\% من إجمالي عدد الأسر في القرى التي تم اختيارهـا مـن واقـع البيانـات حيث بلغت عينـة الدراسـة 200 مبحوثه وهـى ربـة الأسرة أو أكبر النساء أو البنات سناً في الأسرة الريفية. وقد كان
تتازليا حسب الأهمية النسبية لتأثيرها علي المتغير التابع،

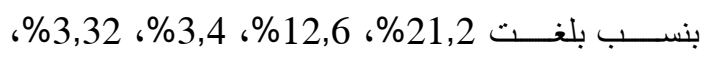
1,7\%، 1\% لكل منها على الترتيب.

رئية نقدية للاراسات السابقة : يتضح من العرض السابق للاراسات التي تتاولت دورالمرأة الريفية في التتمية تعدد في تتـاول البـاحثين لدراسـة أدوار المـرأة الريفيـة في التتمية ، حيث ركزت بعض الدراسات على دور المرأة في المهام الحقليـة وكذلك من خـال نتـاول دورهـا في انتاج الأغذية الزراعية ، في حين تتاولت بعض الدراسـات دور

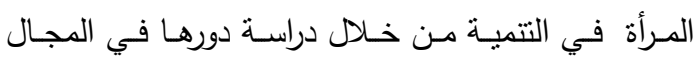
الإجتماعي والاقتصادي والمجال السياسي.

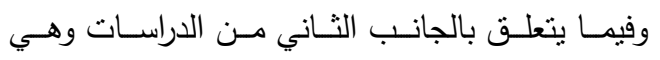
الدراسـات التـي تتاولت دور الإرثـاد الزراعي في تتميـة المرأة الريفية فقد تناولت الدراسات دورالإرشاد الزراعي في تتميـة المـرأة الريفيـة مـن خـلاص التعـرف علي مدى ادراك الريفيـات للأنشـطة الارشـادية وتحديـد درجـة اسـتفادتهن وتسحين مهاراتهن في مجال الزراعة وطبيعة اتجاههن نحو الإرشـاد الزراعـي ، وكـذلك مـن خـلال تطبيـق المفـاهيم

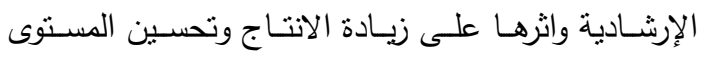
المعرفي والسـلوكي للريفيـات في بعض مجـالات التتميـة (مجال الصحة الأسرية).

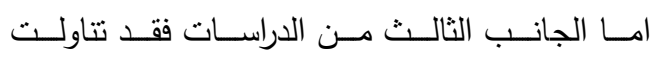
الإحتياجـات الارشـادية للمـرأة مسن خـلال تحديـد معـدل الاحتياجات الإرشادية المعرفية والتنفيذية للمرأة في مجالات

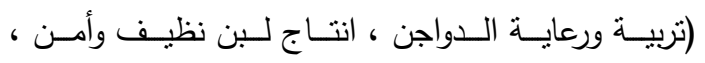
الصـناعات الريفيـة ، انتـاج المحاصـيل ، جمـع وتسـويق

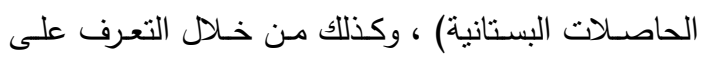
مصسادر حصـول المرثـدات الزراعيـات على المعلومـات الزراعية ومدى كفاية المعلومات المتاحة.

ويتضـح من العرض السـابق ندرة في الدراسـات التي تتاولت دور الإرشـاد الزراعي في تتميـة المرأة الريفيـة في الجمهورية اليمنية ، وتأتي هذه الدراسـة في باكورة الأعمال البحثيـة التي تتاولت هذا الموضسوع الذي مـا يزال خصباً لإجراء المزبد من الدراسات . 
إعطـاء(درجتين) لغيـر المتزوجـة و ( درجـة واحـدة) ل للمتزوجة.

محل الميلاد: ويقصد بـه الدكان الذي ولدت فيه المبحوثـة وتـم قياسـهـ مـن خـلال إعطــاء (تـلاث

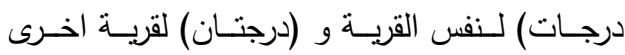

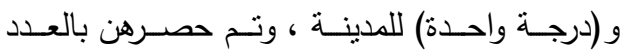
والنسبة المئوية .

المهنة : ويعبر عن العمل الذي تمارسه المبحوثه ، وتم قياسه من خلال سؤال المبحوثه عن نوع العمل الذي تمارسه ، وقد تم توزيع المبحوثات وفقاً لعملهن

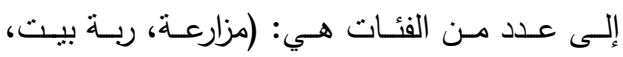
مدرسـة، طالبـة، ممرضـة، كوافيره، خباطـة، بائعـة) حيث أُعطي الدرجات التالية (1 ، 2 ، 3 ، 3 ، 4 ، 5 ، 6 ، 7، 8) على الترتيب ، وتم حصرهن بالعدد والنسبة المئوية. حجم الأسرة: تم قياسه كرقم مطلق يعبر عن عدد الأفراد الذين يعيشون مع المبحوثه في وحدة معيشية واحدة وتم حصرهن بالعدد والنسبة المئوية . عدد الذكور في الأسرة: يقصد به الرقم الخام لعدد

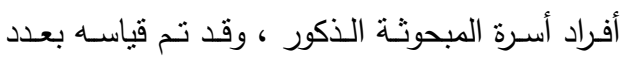
الذكور في الوحدة المعيشة ( الأسرة ) وتم حصرهن بالعدد والنسبة المئوية. عدد الإناث في الأسرة : يقصد به الرقم الخام لعدد

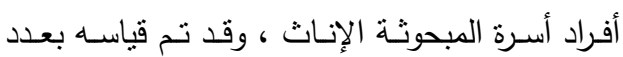
الإناث في الوحدة المعيشة ( الأسرة ) وتم حصرهن

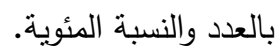

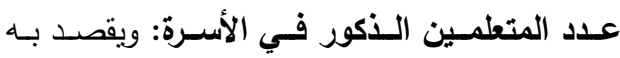

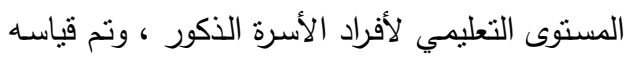
من خلال سؤال المبحوثه عن عدد المتعمين الذكور بالأسرة وتم حصرهن بالعدد والنسبة المئوية.

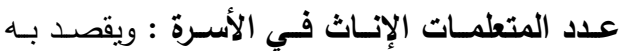
المستوى التعليمي لأفراد الأسرة الإناث، وتم قياسـ الإنس من خلال سؤال المبحوثه عن عدد المتعلمات الإناث بالأسرة ونم حصرهن بالعدد والنسبة المئوية.
توزيـع المبحوثـات في مديريات الدراسـة على النحو

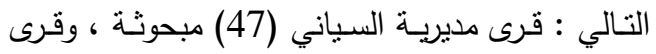
مديريـة بعدان (59) مبحوثـة، وقرى مديريـة العدين (60) مبحوثة، وقرى مديرية العدين (34) مبحوثة .

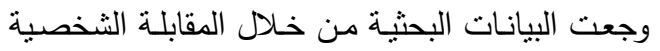
باستخدام أستمارة استنيان أعدت لأغـراض الدراسـة.

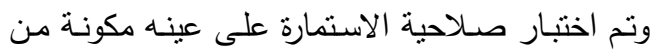
(10) مبحوثات مـن قريـة (القاسـية) بمديريـة القفر وخارج نطاق العينة البحثية ـ وتم جمع بيانات الدراسة خلال الفترة من شهر فبراير إلى يونيو 2016م.

ثانياً : المتغيرات البحثية وكيفية قياسها

اشتملت الدراسة على عدد من المتغيرات منها (31) متغيرا مستقلاً ومتغيرا تابعاُ واحدا هو دور الإرشاد الزراعي العني

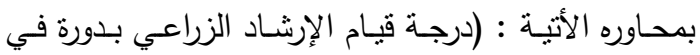
تتمية المرأة الريفية في مجالات التتمية الددروسة، استفادة

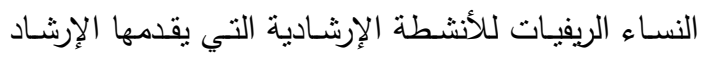
الزراعي)، وتم قياس المتغيرات البحثية كالأتي :

أولاً: قياس المتغيرات المستقلة 1. العمر: وتم قياسه كرقم مطلق يعبر عن عدد سنوات

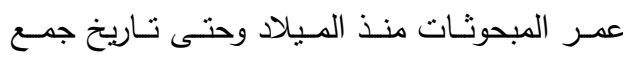
البيانـات لأقرب سنة ميلاديـة وتم حصرهن بالعدد

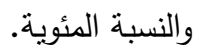
2. الحالـة التعليميـة : ويعبر عنه بالمسنوى التعليمي الرسمي الذي أتنتها المبحوثات في مختلف مراحل التعليم الرسـي ، وتم قيـاس هذا المتغير بمقياس

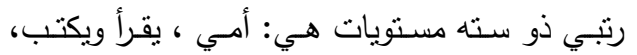
حاصل على ابتدائية، إعدادية، ثانوي، حاصل على دلى دلى

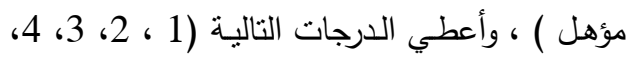
5، 6) على الترتيب ، وتم حصرهن بالعدد والنسبة المئوية . 3. الحالــة الزواجيـة : قصــــــــا الحالـة الاجتماعبـة للمبحوثة وقت استنيانها سواء كانت غير متزوجة لم يسبق لها الزواج أو متزوجة ، وتم قياسها من خلال 
سـؤال المبحوثـه عن الاعمـال التـي يمارسـها افـراد

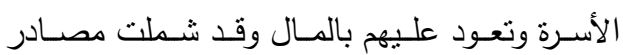

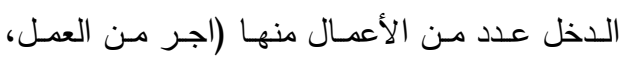

إيجار أرض زراعية ، بيع محاصيل زراعيه ، تجارة

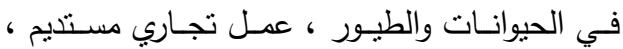

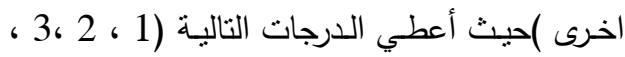

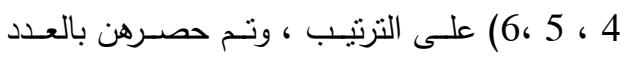

$$
\text { والنسبة المئوية . }
$$

17. متوسـط الــخل الثـهـري للمبحوثـة : تعبر عن

منوسط العائد الذي تحصل عليه المبحوثة مقابل القيام بنشاط معين ، وقد تم قياسه من خلال الرقم

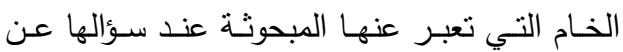
متوسط الدخل الثـهري لها ، وتم حصدرهن بالعدد

$$
\text { والنسبة المئوية . }
$$

18. ملكية الأرض الزراعية لأسرة المبحوثة : تعبر فيما

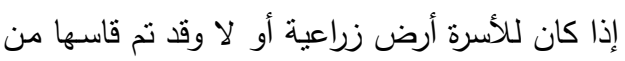

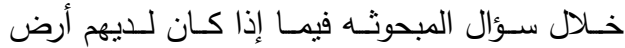
زراعية أو لا حيث تم إعطاء (درجتين ) في حال

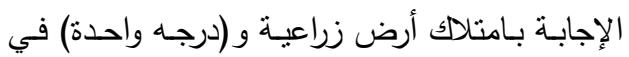
حـال عـدم امـتلاك أرض زراعيـة ، وتـم حصـرهن بالعدد والنسبة المئوية . 19. حجم حيازة الأرض الزراعية لأسرة المبحوثة : هي العيدئ إجمالي الحيازة الأرضية الزراعية لدى أسرة المبحوثة

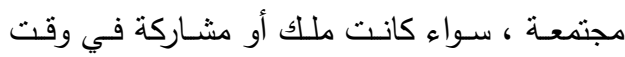
إجراء الدراسة ، وقد نم قياسها بالقصبة وهي الوحده المحلية المتعارف عليها حيث نساوي القصبة 57 متر مربـع تقريبـاً، وتـم حصـرهن بالعـد والنسـبة المئوية. - مان. 20. حيازة الآلات الزراعيـة للأسرة : يقصد بـه في هذه

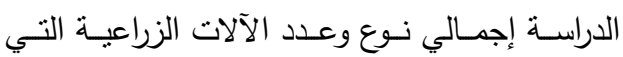
تمتلكها الأسرة ويتم استخدامها في أرض الأسرة فقط أو تأجيرها للغير وشملت الحيازة على امتلاك حراثة

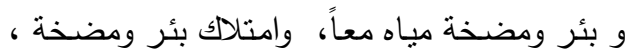

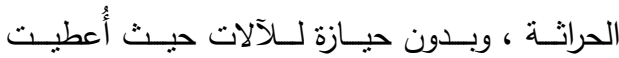

11. رب الأسرة : وتعبر عن الثخص الذي يقوم بإعالة

الأسرة ( مسئولية ومهام رعاية وتدبير أمور الأسرة) ، وتم قياس هذا المتغير بمقياس ذو خمس مستويات هي: ( الاب، الام، الزوج، الابن، الأخ، أخو الزوج،

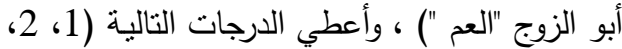

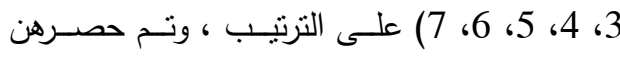
بالعدد والنسبة المئوية . 12. عمل رب الأسرة أو عائل الأسرة : تعبر عن المهنة التـي يمارسهـا رب الأسـرة ، وتـم قياسـه مـن خـلال سؤال المبحوثه عن نوع العمل الذي يمارسه عائل الأسرة ، وتم حصرهن بالعدد والنسبة المئوية. 13. المستوى التعليمي لرب الأسرة : ويعبر عن المستوى

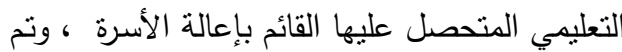
قياس هذا المتغير بمقياس رتبي ذو سته مستويات هي: أمسي ، يقرأ ويكتب ، حاصل على بلى ابتدائيـة،

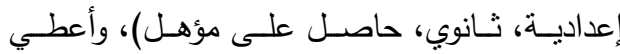

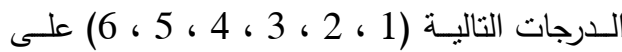
التزتيب ، وتم حصرهن بالعدد والنسبة المئوية . 14. درجـة تـوفر الخــمات بالقريـة: تعبر عن البنيـة

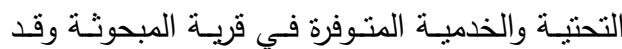
أُعطي للإجابة بحاله نوفر الخدمة (بدرجتين) وفي

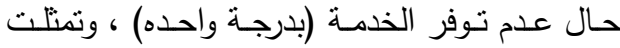

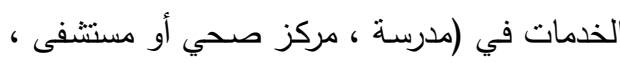
جمعية زراعية ، مسجد ، سوق تجارية ، شبكة نقل ومواصلات ، مركز إرشادي ) وتم حصرهن بالعدد نداء والنسبة المئوية . 15. إجمالي الدخل الثـهري للأسرة : تعبر عن العائد

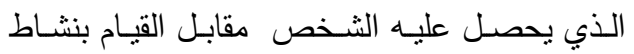
معين ، وقد تم قياسه من خلال الرقم المطلق الذي لئ تعبر عنه المبحوثة عند سؤالها عن الدخل الثهري

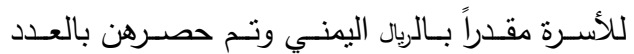
والنسبة المئوية. 16. مصادر الاخل الأسري : يعبر عن الأجر المتحصل

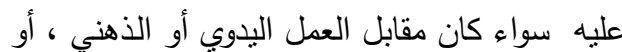

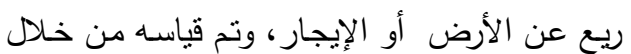




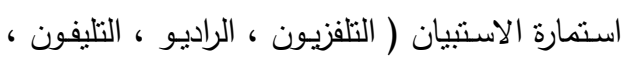

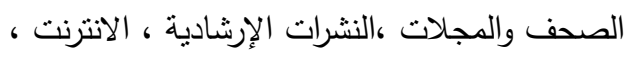

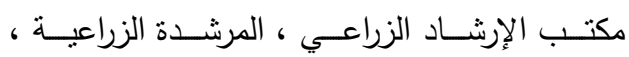

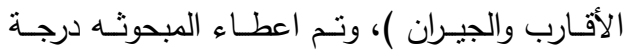

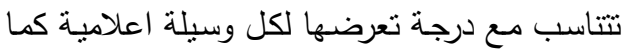

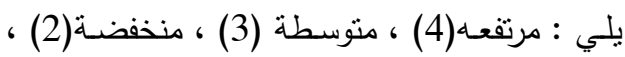
لم تستقد (1) ، ونم حصرهن بالعدد والنسبة المئوية. 24. الإنفتاح الجغرافي : يقصد بـه التحرك المكاني أي

مدى تردد المبحوثه على القرى الدجاورة لها وكذلك الكرات المدن والمراكز والمحافظات داخل اليمن ، وترددها

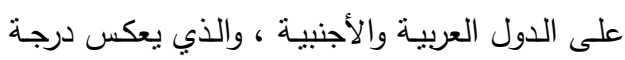

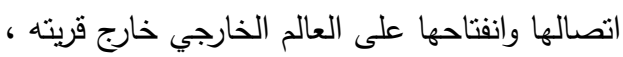
واعطيت الاستجابات كثبر (4) ، احياناً (3) ، نادراً (2) ، ابـاً (1) ، وفي حسال الاجابـة بكثبر واحيانـاً

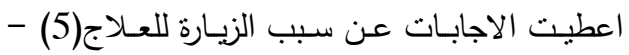

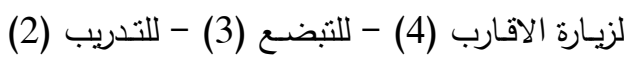
- وللمناسـبات (1)، وتم حصـرهن بالعـد والنسبة النبة المئوية .

25. درجـة القياديـة : ويقصد بـه إدراك المبحوثه لقدرتها

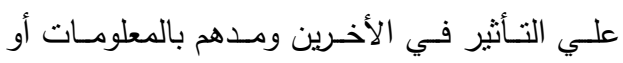
الاستشــارات التـي يحتاجونها ،وتـم مـنح المبحوثـه

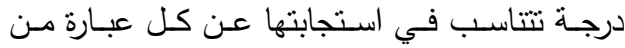

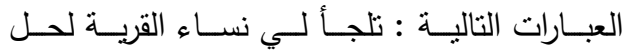

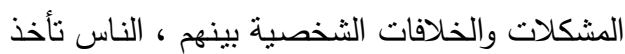

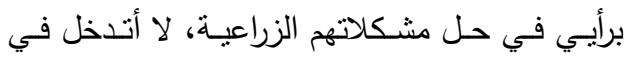

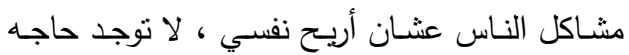

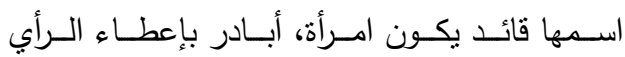

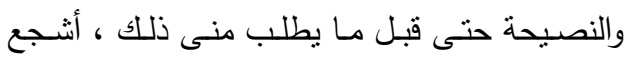

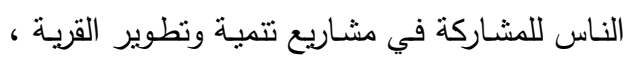
حيث اعطيت العبارات الايجايية رقم (1،5،2، 1،

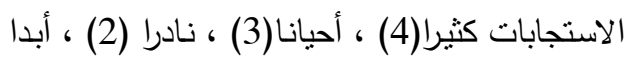

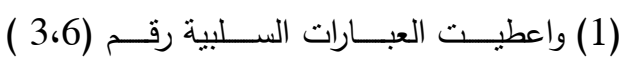

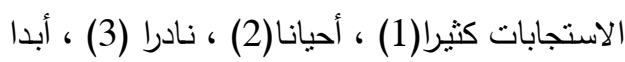
(4) ، وقد وتم حصرهن بالعدد والنسبة المئوية.

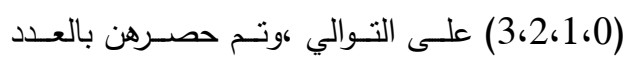
والنسبة المئوية . .

21. تريبـة الحيوانـات والطيـور : يقصد بها الحيوانـات

والطيور التي تحوزها أسرة المبحوثة وقد نم حسابها بإعطاء (درجة) في حال عدم الحيازة و (درجتين) في حال حيازة الحيوانات والطيور، وتم حصرهن بالعدد والنسبة المئوية .

22. المستوى المعيثي : يقصد به المستوى الحالي الذي توجد عليه أسرة المبحوثه ، وتم قياس هذا المتغير

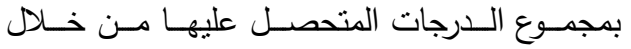

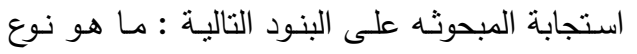
المسكن الذي تشكنون فيه : ملك (3) ، إيجار (2)، مشترك (1)، ماهي نوعية مادة البناء : حجر (2)،

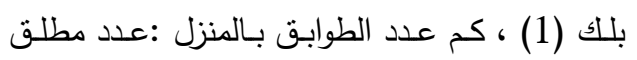

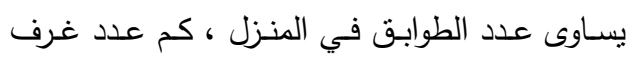
المنزل: عدد مطلق يساوى عدد الغرف في المنزل ،

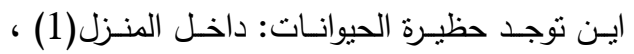

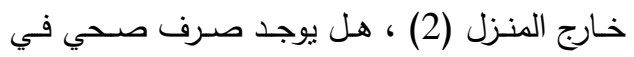

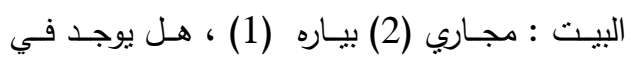

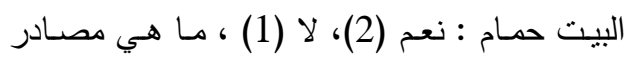

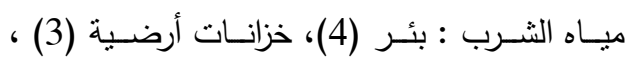
مشروع عمومي (2)، مشروع أهلي (1) ، ينت نقل

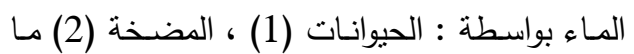
هي مصسادر الإنـارة: كهربـاء عموميـة (3)، مولد

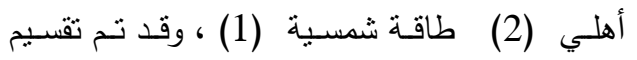
المبحوثات وفقاً للمستوى المعيشي لأسرهن الى ثلاث

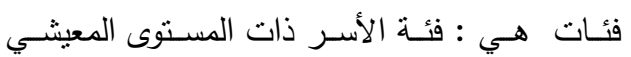
المنخفض شملت من (5-15 درجة) ، فئة الأسر المبر

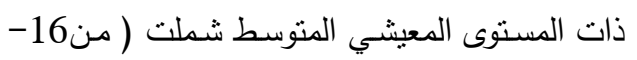
26 درجـة ) ، فئسة الأسـر ذات المستوى المعيثـي المرتفع شملت (من 27-37 درجة) ، وتم حصرهن بالعدد والنسبة المئوية. 23. الإنفتاح الثقافي : يقصد به مدى تعرض المبحوثن

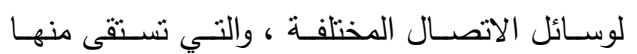

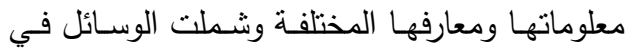


والاجتماعية والمدنية المختلفة ، وتم قياسة من خلال

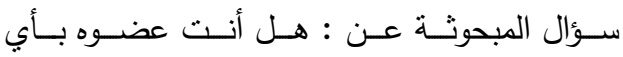

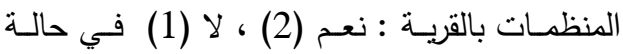
الإجابة بنعم : ما هي هذه المنظمة : هل هي خيرية

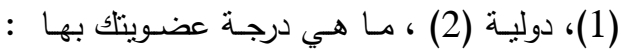
رئسيس مجلس (3) ، عضـو مجلس (2) ، عضـو

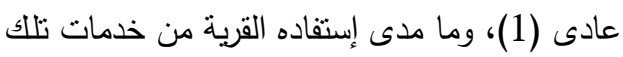

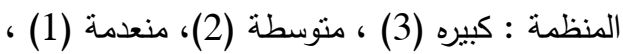
وقد وتم حصرهن بالعدد والنسبة المئوية. التدريب : يقصد به مدى تعرض المبحوثة لدورات

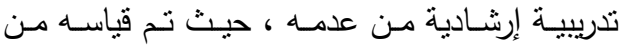
خلال سؤال المبحوثة عن حضورها لدورات تدريبية مقدمة من الإرشاد الزراعي أو عدم حضورها لدورات

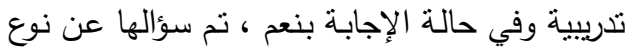
الدورة التكرييية التي حضرتها ، ومن ثم سؤالها عن موعد أخر دورة حضرتها ومدتها مقاسة بعدد الأيام، وفيما يتعلق بدرجة الاستفادة من هذه الدورات فقد تم حسابها من خلال إعطاء درجات لكلا من الإجابات

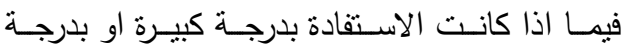
متوسطة أو الاستفادة بدرجة قليلة او الإجابـة بعدم

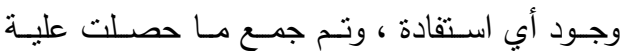
المبحوثة من عناصر التدريب ، وهذه الدرجة تمثل درجة تعرض المبحوثة للتدريب ، وقد وتم حصرهن بالعدد والنسبة المئوية. 31. اتجاه المبحوثات نحو الإرشاد الزراعي : يقصد بها الدرجة التي تعبر عن شعور الريفيات وميلهن نحو

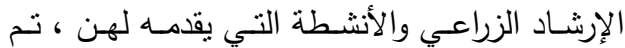
قياسه بإعطاء قيم رقميه تمثل مجموع الدرجات التي لإرتي

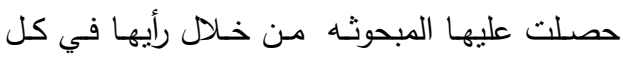

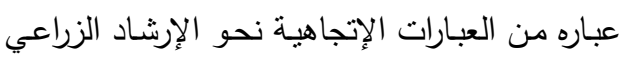
والانشطة التـي يقدمها ، وقد شـملت على ثمانيـة عشر عبارة اتجاهية ، منها (12) عبارة ايجابية وهي

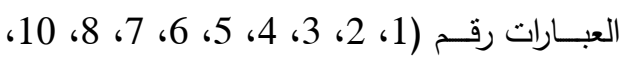
16،17، 18) حيث أعطي الاجابات التالية (موافقة

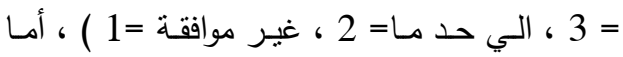

26. الانتماء للمجتمع المحلي : يقصد بـه مدى شعور المبحوثة بأنها جزء من مجتمعها ، والإيمان المشترك الإك بأن احتباجات الأفراد يلبيها شعورهم بالالتزام بالبقاء سـوياً ، وتم قيـاس هذا المتغيـر مـن خـلال سـؤال المبحوثه عن رايها في سبع عبارات تعكس شعورها بانتمائها لمجتمعها المحلى وشملت العبارات التالية (من الصعب أن أجد مكان أعيش فيه أفضل من قريتي، أزعل لمـا أنشوف شيء يسئ للقريـة ، قليل جداً ما أثنارك في مشروعات تتمية وتطوير القرية، أحس إن القرية هذه مش قريتي، لو اجتتى فرصـة

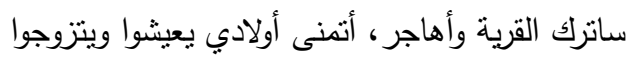
في نفس القرية، الواحدة لازم ترجع بلده مهما طال الزمن) ، وقد وتم حصرهن بالعدد والنسبة المئوية . لدرجـة الـوعي العـام : يقصد بـه المحصـول الفكري

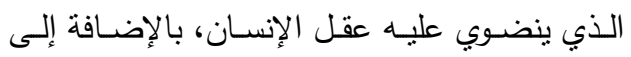
وجهات النظر المختلفة التي يحتوي عليها هذا العقل على الإنال والتي تتعلّق بالمفاهيم المختلفة التي تتمحور حول القضايا الحياتيّة والمعيشيّة ، فنقول إنه شخص يؤمن

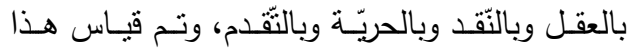
المتغير من خلال سؤال المبحوثه عن رايها في عدد مـن القضـايا الاجتماعيـة التي تعكس وعيهـا العـام حول تلكك الموضوعات ، وقد وتم حصرهن بالعدد والنسبة المئوية . 28. المشـاركة غير الرسـمية : يقصد بها مدى إسـهام ومشاركة المبحوثه في الأنشطة الاجتماعبة والخدمية

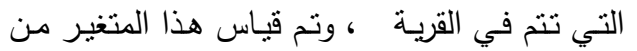
خلال سؤال المبحوثه فيما إذا انشئ هذا النشاط في

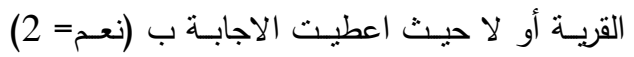
والاجابـة ب (لا = 1 ) ) وفي حالـة الاجابـة بنعم تم سؤال المبحوثه عن مشاركتها في النشاط من عدمه، واعطي الاستجابات عن نوع المشاركة ( ماديه =5، عينيـة=4 ، بالجهـ = 3 ، بـالرأي = 2 ، بالدعايـة = 1 ) ، وقد وتم حصرهن بالعدد والنسبة المئوية. 29. المشاركة المنظمية : ويقصد به مشاركة المبحوثات فــي الجمعيـات والمنظمــات التعاونيــة والخيريــة 
بالاستفادة بدرجة (كبير) ودرجتان في حالة الاجابة بالاستفادة بدرجة (منوسطه) ، ودرجة واحدة في حالة الاجابة بالاستفادة بدرجة (منخفضة). ثالثاً :أساليب التحليل الاحصائي لتحليـل بيانــات الدراســة ، تــم اســتخدام البرنــامج الإحصـائي SPSS حيـث اسـتخدم الإحصـاء الوصـفي

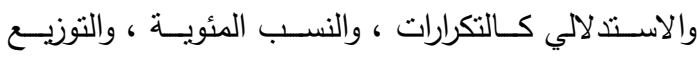
التكراري ، وبعض مؤشرات التحليل الإحصائي كالمتوسط الحسابي والاتحراف المعياري لعرض النتائج.

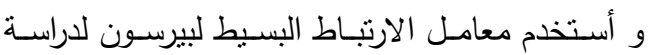
طبيعة العلاقة الارتباطية بين المتغيرات المستقلة للاراسة

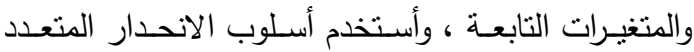

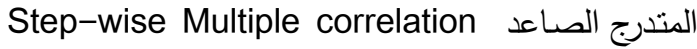
and Regression Analysis النسبي لكل من المتغيرات المستقلة مجتمعة التي ثبت معنوية علاقتها في المتغير التابع.

\section{رابعاً: وصف عينة الدراسة}

يتبين من بيانـات الجدول رقم (1) فيما يتعلق بسن

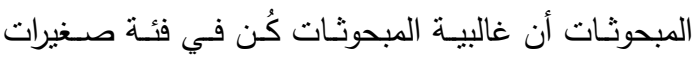

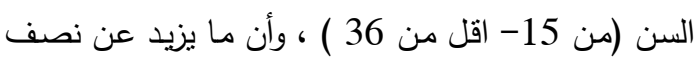

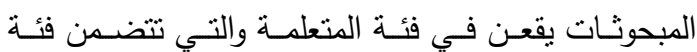
(إبتدائي ، إعدادي ، ثانوي ، حاصل علي موهل ) ، وتبين

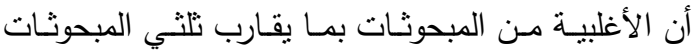

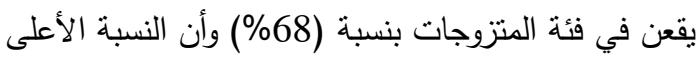
من المبحوثات هن من مواليد نفس القرية بنسبة (73\%) في حين أن الاغلبية من المبحوثات بما يزيد عن نصف

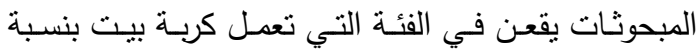
(59,5) في حين أن ما يقرب من ثلثي المبحوثات يقعن

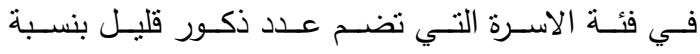
(62,5\%)، وأن غالبية المبحوثات يقعن في الفئة الصغيرة بنسبة (80,5\%) فيما يخص عدد أفراد الأسرة الإناث ،
العبارات السلبية فكانت (6) عبارات وهي العبارات

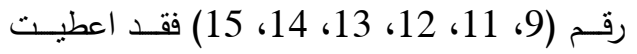

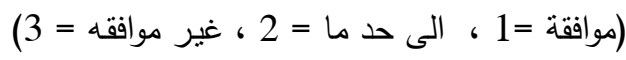

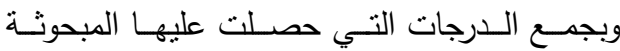
نحصل على درجة كلية تعبر عن اتجاه المبحوثات نحو الارشاد الزراعي والاتشطة التي يقدمها.

ثانياً المتغيرات التابعة: أ- درجة قيام الإرشاد الزراعي بدوره في تنمية المرأة الريفية في المجالات المدروسة

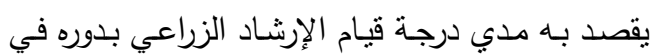
تتميـة المرأة الريفية في المجالات المدروسـة والتي تهدف الى مساعدة النساء الريفيات على تتمية وتطوير انتاجهن وتحسين مستوى ادائهن للعمل الزراعي والمنزلي ،وتم قياس هذا المتغير من خلال جمع الدرجات المتحصل عليها من استجابات المبحوثات لكل نشاط من الانشطة المتعلقة بكل

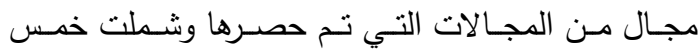

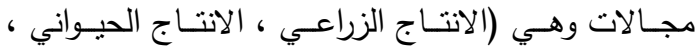

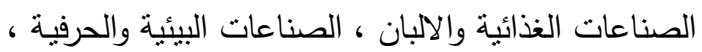
ومجـال الصـحة )، وتم قيـاس الدرجـة الكليـة لدرجـة قيـام الإرشاد الزراعي بدوره في تتمية المرأة الريفية في المجالات

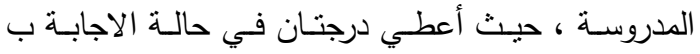
(نعم) للنشاط الذي قام به الإرشاد الزراعي، ودرجة واحدة

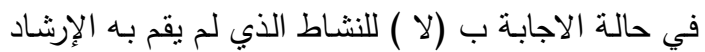

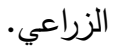

ب- درجة استفادة النساء الريفيات المبحوثات من

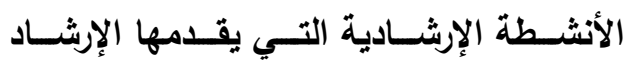

$$
\text { الزراعي: }
$$

يقصد بها الجوانب الإيجابية الني تتحقق لاى المرأة

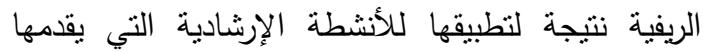

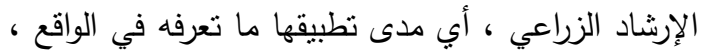
و نم قياس ذللك من خلال جمع الدرجات المتحصل عليها من استجابات النساء الريفيات المبحوثات لكل نثاط من الأنشطة وذلك بإعطاء ثلات درجات في حالة الاجابة 
The role of agricultural extension in the development of rural women in ............. 